(1) Nordic Council of Ministers

\title{
Nordic co-operation on food information
}

ACTIVITIES OF THE NORDIC FOOD ANALYSIS NETWORK 2013-2016 



\section{Nordic co-operation on food information}

Activities of the Nordic Food Analysis Network 2013-2016

Liisa Valsta, Helena Pastell, Sanni Aalto and Suvi Virtanen (Eds.)

TemaNord 2017:503 
Nordic co-operation on food information

Activities of the Nordic Food Analysis Network 2013-2016

Editors: Liisa Valsta, Helena Pastell, Sanni Aalto and Suvi Virtanen

ISBN 978-92-893-4842-3 (PRINT)

ISBN 978-92-893-4843-0 (PDF)

ISBN 978-92-893-4844-7 (EPUB)

http://dx.doi.org/10.6027/TN2017-503

TemaNord 2017:503

ISSN 0.908-6692

Standard: PDF/UA-1

ISO 14289-1

(c) Nordic Council of Ministers 2017

Cover photo: unsplash.com

Print: Rosendahls

Printed in Denmark

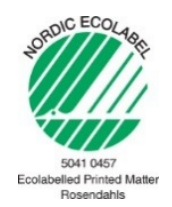

Although the Nordic Council of Ministers funded this publication, the contents do not necessarily reflect its views, policies or recommendations.

\section{Nordic co-operation}

Nordic co-operation is one of the world's most extensive forms of regional collaboration, involving Denmark, Finland, Iceland, Norway, Sweden, the Faroe Islands, Greenland, and Åland.

Nordic co-operation has firm traditions in politics, the economy, and culture. It plays an important role in European and international collaboration, and aims at creating a strong Nordic community in a strong Europe.

Nordic co-operation seeks to safeguard Nordic and regional interests and principles in the global community. Shared Nordic values help the region solidify its position as one of the world's most innovative and competitive. 


\section{Contents}

Preface

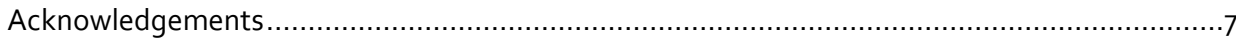

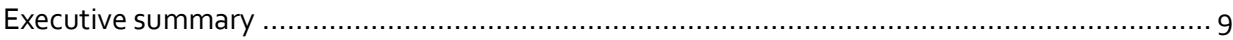

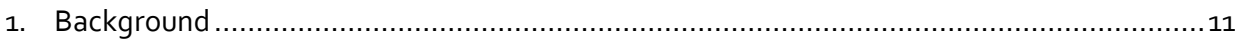

2. The Nordic network of excellence in food composition and chemical food analysis in the Nordic countries.....

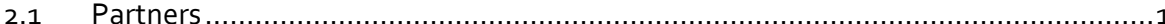

2.2 National Food Institute, Technical University of Denmark (DTU), Denmark ............14

2.3 National Institute for Health and Welfare (THL), Finland...................................15

2.4 Finnish Food Safety Authority Evira, Finland ..............................................15

2.5 Matís - Icelandic Food and Biotech R\&D, Iceland ...............................................

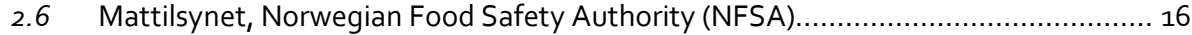

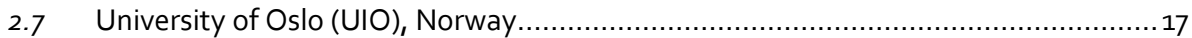

2.8 National Food Agency (NFA), Sweden ........................................................... 17

2.9 National Institute for Health Development (NIHD), Estonia ................................17

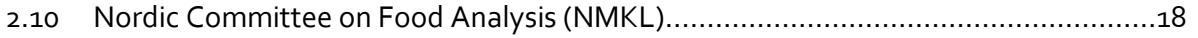

3. Activities of the Nordic Food Analysis Network between 2012-2016 ........................... 19

3.1 Summary of the network activities .............................................................. 19

4. Nutrient analysis programmes in the Nordic countries to update the national food

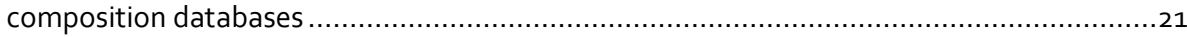

4.1 Danish National Food Institute (DTU) .........................................................21

4.2 National Institute for Health and Welfare (THL), Finland....................................23

4.3 Icelandic Food and Biotech R\&D, Matís ......................................................... 25

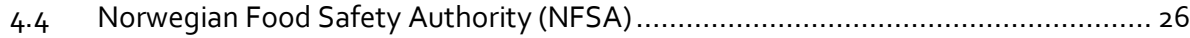

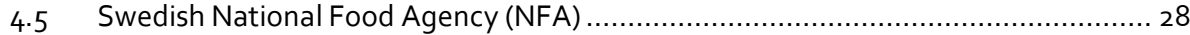

4.6 National Institute for Health Development (NIHD), Estonia .................................. 30

5. Comparability of nutrient values of foods and fortification programmes in the Nordic

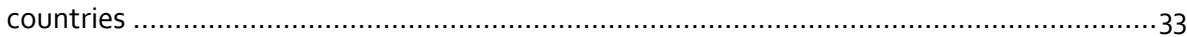

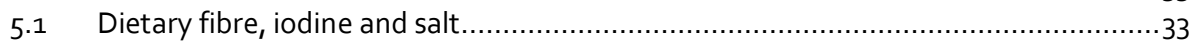

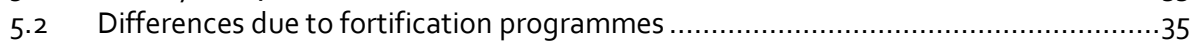

6. Towards improved Nordic co-operation - What do we need to succeed? .........................37

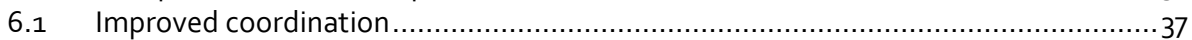

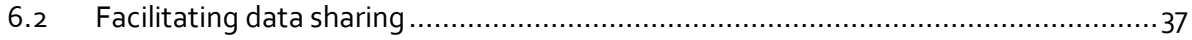

6.3 Nordic networking - valuable peer-support ................................................ 38

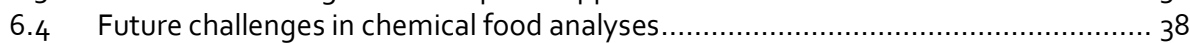

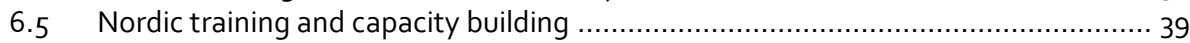

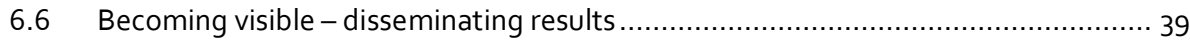

6.7 Thinking outside the box - A common Nordic food composition database.............. 40

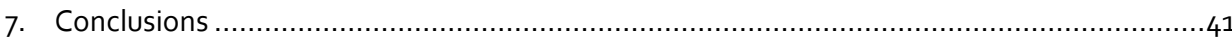

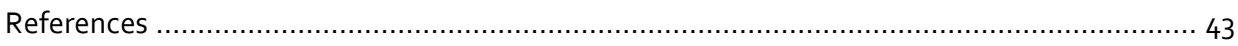

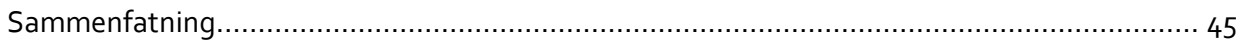

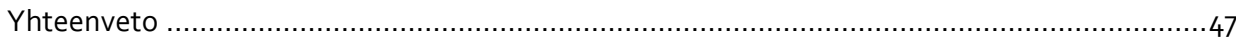

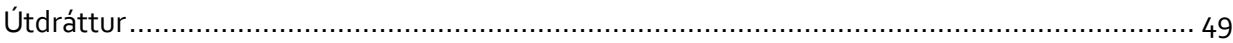

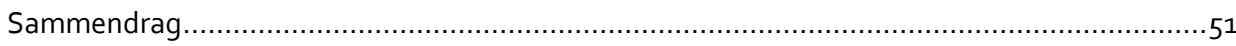

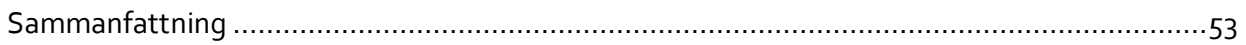




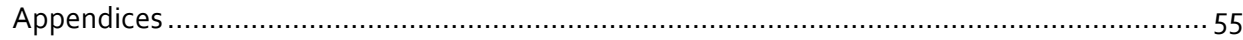

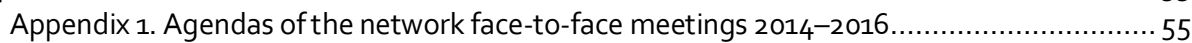

Appendix 2. The sampling plan for the Nordic Food Analysis Network - iodine and sodium

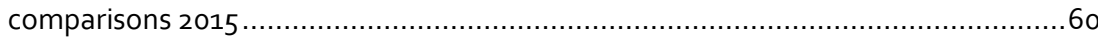

Sampling procedure in Finland to be applied as closely as possible by other countries........61

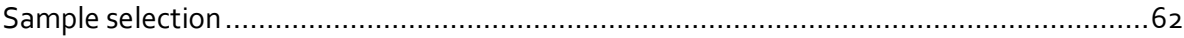

Sample compilation for the analyses ......................................................................64

Appendix 3 . Examples of fortification programmes of vitamins and minerals, which may result inconsistent food composition of equivalent foods in the Nordic Countries....66

Appendix 4. Contact persons, addresses and contact information.... 


\section{Preface}

The quality of food composition information is of great significance, considering the vast and important use of the data: for national dietary advice, for food nutrient labelling and in epidemiological research. The Nordic countries have collaborated, in the field of food composition information, for several decades. In recent years, an increased interest in food analyses, the ever-reducing resources for carrying out analytical food composition information projects and, at the same time, improved possibilities for sharing information have motivated the activities of the Nordic Food Analysis Network.

The activities of this project were initiated in a meeting of the food composition database managers and actors in the chemical food analysis field, held in Reykjavik, on 2 June 2012, in connection with the $10^{\text {th }}$ Nordic Nutrition Conference. From the start, it was obvious that the Nordic countries have many similarities with the Baltic countries in the areas of food culture and food composition. Thus, a greater, closer collaboration was found useful to provide synergy and a greater pool of knowledge. As a result, Estonia has been included in this network and has actively participated, in the activities, since 2014.

This report describes the activities that have taken place in the area of chemical food analysis, for the national food composition databases of the Nordic countries, at the national level, since 2000 and specific activities of this network between the years of 2013-2016. This network picked fibre, iodine and sodium as specific nutrients to focus on during this project, and comparative analyses of selected Nordic food items were carried out during this project with external funding.

Members of this project are listed in the Table 2 of this report. All members have contributed to the content of this project and the report, edited by Liisa Valsta, Helena Pastell, Sanni Aalto and Suvi Virtanen. 



\section{Acknowledgements}

The work of the Nordic Food Analysis Network (NFAN) group was funded by the Nordic Council of Ministers by the Nordic Working Group for Diet, Food \& Toxicology. The NFAN group acknowledges the participation of other experts in the group meetings and the Satellite Symposium organized in connection to the $11^{\text {th }}$ Nordic Nutrition Conference in June, 2016:

- Wulf Becker

- Susanna Kariluoto

- Taija Kosonen

- Anders Mogensen

- Susanne Westenbrink 



\section{Executive summary}

Quality of food composition information is of great significance considering the vast and important use of the data: for national dietary advice, for food nutrient labelling, and in epidemiological research. In order to have good quality data for foods consumed in the Nordic countries, sampling and analysis of food needs to be performed to determine the nutrient composition of interest.

The Nordic Food Analysis Network project (NFAN), that was carried out between 2013-2016, focused on creating a common, simple communicational platform to share history and plans on chemical food analyses. In addition, it focused on sharing developments in the areas of new analytical methods, especially of dietary fibre, iodine and sodium (i.e. salt).

An extranet site was set up, where partners updated their chemical food analysis activities, for others to observe and be aware of. The platform was found to be informative, although updating it was sometimes found to be cumbersome or forgotten. This kind of activity needs active coordination to become useful.

Also, comparative analyses of fibre, iodine and sodium concentrations of selected Nordic foods were carried out with external funds and the results were shared, discussed and disseminated among the project group and a broader audience. The comparative analyses showed diverging results, even when the same analytical methods and procedures are used. A comparison, organized by the network, of the conditions in the different countries, showed several reasons for this. The main reasons for different nutrient compositions between the countries was found to be differences in fortification programmes and in animal feeding practices between the countries.

The NFAN network organized three physical meetings and one open satellite symposium during the project, which served as platforms to update the partners on national developments in the field and discuss future visions - even wild ideas. The meetings were highly appreciated, partly due to the fact that the critical mass of competence, both for food composition data compilers and food chemists at the national level, in all Nordic countries, is declining. The discussions not only focused on the tasks of this project, but also served as a forum to discuss the broader challenges in the area as well as strategies to better disseminate food data and how to improve the dialogue between data providers from the food industry, and the data users and other stakeholders. 
For future actions, the Network has recommended that:

- The Nordic countries should continue to keep each other informed about chemical food analysis plans to facilitate possible common analyses and to facilitate other synergistic activities and method development. Moreover, there is a continuous need for a well-structured and simple-to-use communicational platform in the future, where all the information is stored and updated.

- New chemical analysis data should be compiled in the food composition databases and be more widely used in the future.

- The background information on the analysed nutrient values, e.g. the sampling procedures, methods, sample description (e.g. fortification practices, animal feeding practices in the country) are crucial for the data users, and therefore, should be disseminated together with the values.

- A common Nordic training programme for young actors in the fields of chemical food analysis and food composition data compilation should be considered, to assure high quality outputs, in the future.

- Harmonization efforts for the production of food composition information, according to established guidelines (e.g. Greenfield \& Southgate, 2003) and updated rules to calculate the activity of nutrients (Institute of Medicine 2000, Nordic Council of Ministers 2012), should be continued.

- Re-evaluation of the rules and procedures for use of existing food composition data should be carried out. This could be done by performing an updated evaluation on the handling of the nutrient values, i.e. to carry out an update of the former Norfoods 2000 project (Norfoods 2000-project group, 2002). 


\section{Background}

Food composition and up-to-date chemical analysis of food items are essential in nutritional and epidemiological research, and in the evaluation of the nutritional and toxicological risks. Moreover, this information is used in nutrition labelling and food recommendations.

The selection of available food items changes constantly and the food industry produces hundreds of new food items every year. Thus, the selection of the food items, to be analysed, is broad and variable; however, the resources, for analysis, are rather limited. This means that it is essential to work together, to use the limited resources in the most advantageous way.

There is an existing infrastructure for chemical food analysis; however, additional resources are needed for deeper integration and co-operation. This will lead to a better distribution of work and the elimination of overlap. Deeper integration and cooperation could also facilitate an increase in the number and range of the chemical analyses and improve quality. In addition, the results of the project may even be utilized in the European scale via the EuroFIR network (www.eurofir.org).

In most of the Nordic countries, chemical food analysis is already a well-established procedure. In Finland, however, the national chemical food analysis programme, for the national food composition database (Fineli), was only recently started. Nevertheless, the accumulation of experience and knowledge, as a consequence of the co-operation, may be exploited in each of the Nordic countries and their neighbouring countries (e.g. Estonia), despite differences in analytical backgrounds. 



\section{The Nordic network of excellence in food composition and chemical food analysis in the Nordic countries}

\subsection{Partners}

The participants in this project were experts from the chemical food analysis and food composition database management, as well as the information technology fields in the Nordic countries and Estonia. In addition, the Nordic Committee of Food Analysis (NMKL) has participated as a silent member in the project (Table 1).

Table 1: Partner institutions of the Nordic Food Analysis Network project

National Food Institute, Technical University of Denmark (DTU), www.food.dtu.dk Denmark Nutrition Unit, National Institute for Health and Welfare (THL), www.thl.fi

Finland Finnish Food Safety Authority Evira www.evira.fi

Matis ohf. / Icelandic Food and Biotech R\&D (Matis), www.matis.is

Finland

Mattilsynet, Norwegian Food Safety Authority (NFSA), www.mattilsynet.no Norway University of Oslo (UIO), www.uio.no

National Food Agency (NFA), www.slv.se

National Institute for Health Development (NIHD), www.tai.ee Estonia

Nordic Committee on Food Analysis (NMKL), www.nmkl.org

Nordic

Several experts from each institution have contributed to the activities of the network. The project has been coordinated by the National Institute for Health and Welfare (THL) in Finland. The work has been led by an info-coordinator, namely, Jenna Rautanen (from June 2013 to January 2015) and by Liisa Valsta (from January 2015 to December 2016).

The active members of the network that have contributed to this project are presented in Table 2, with a more detailed description of the activities of the specific organisations being provided in the following chapters. 


$\begin{array}{lc}\text { Members } & \text { Institution } \\ \text { Tue Christensen, Erling Saxholt, Kirsten Pilegaard, Ellen Trolle, Pia Knuthsen } & \text { DTU } \\ \text { Suvi Virtanen, Heli Reinivuo, Heikki Pakkala, Salla Luhtala, Jenna Rautanen, Heli Kuusipalo, } & \text { THL } \\ \text { Sanni Aalto, Liisa Valsta } & \text { Evira } \\ \text { Helena Pastell, Tiina Putkonen, Tiina Ritvanen, Aliki-llona Rainakari (neé Ninios) } & \text { Matís } \\ \text { Ólafur Reykdal, Heiða Palmadóttir, Hrönn Ólína Jörundsdóttir, Bryndís Eva Birgisdóttir } & \text { NFA } \\ \text { Anna-Karin Lindroos, Marianne Arnemo, Anders Staffas, Veronica Öhrvik, Rasmus Grönholm, } \\ \text { Ninna Lundberg-Hallen, Hanna Sara Strandler } & \text { NFSA } \\ \text { Astrid Norbotten, Ellen Kielland, Jorån Østerholt Dalane } & \text { UIO } \\ \text { Monica Hauger Carlsen } & \text { TAI } \\ \text { Ann Jõeleht, Liis Kambek } & \text { NMKL }\end{array}$

the project of the Nordic Food Analysis Network

\subsection{National Food Institute, Technical University of Denmark (DTU), Denmark}

The aim of the National Food Institute, Technical University of Denmark, is to establish the scientific foundation to give consumers better access to high-quality healthy safe food, to promote health and to prevent diseases related to diet and chemical or microbiological contamination in the food we eat. The Institute conducts the Danish National Survey of Diet and Physical Activity and, in conjunction with this work, a Danish Food Composition Database is maintained, in collaboration with the Danish Veterinary and Food Administration and their laboratories. The main work of data compilation is done at the Division for Risk Assessment and Nutrition, while surveillance of the analysis is mainly done by the laboratories. The Danish Food Composition Database is considered to be the third pillar of all nutritional work, the Danish National Survey of Diet and Physical Activity and the dietary recommendations (including the Nordic Nutrition Recommendations and the Danish Food based Dietary Guidelines) being the two other pillars. E.g. FCD is used for research and education, for nutrition counselling and advisory tasks, and by the producers for nutrition labelling. Data have been available as printed tables, since 1983. The last major printed version is from 1995, and has been followed by comprehensive data, published on the Internet, since 2002. The latest edition of the Danish Food Composition Tables is from 2015, and can be found here: http://frida.fooddata.dk. In connection with cutbacks at the Danish 
Veterinary and Food Administration and their laboratories, future work has been discussed during 2016 and reorganisation will occur from January 2017.

\subsection{National Institute for Health and Welfare (THL), Finland}

The National Institute for Health and Welfare (THL) is a research and development institute under the Finnish Ministry of Social Affairs and Health. The THL studies population health and welfare, the effectiveness of health and welfare policies and services, environmental health as well as social problems.

Fineli is the Finnish national food composition database maintained by the Nutrition Unit of the National Institute for Health and Welfare (THL). Food composition of Finnish food items and food products have been compiled in the database. The food composition database includes over 5,000 foods and over 300 nutrient factors. The first version of Fineli was established in 1984. In addition, the first online version of Fineli was published in 1999 and is, currently, freely available as open data.

Finnish Food Composition Data is needed in nutrition research, dietary counseling and diet therapy, the assessment of nutritional and toxicological risks, product development, the implementation of nutritional recommendations as well as in development and follow-up of catering services. The national food composition database is of especial importance for small enterprises that cannot receive information for the mandatory nutrient value labels from elsewhere.

\subsection{Finnish Food Safety Authority Evira, Finland}

The Finnish Food Safety Authority Evira, is a governmental agency under the Finnish Ministry of Agriculture and Forestry, with about 650 employees, at eight locations, in Finland. Activities at Evira aim at ensuring food safety, promoting animal health and welfare, and developing the prerequisites for plant and animal production, and plant health. Amongst other activities, Evira's laboratories include analytics related to food safety and composition. Laboratory operations include national and international reference laboratory activities.

Fineli is a national food composition database that is maintained by the National Institute for Health and Welfare (THL). Evira is a member of a Fineli working group, which is coordinated by the THL. In the group, Evira takes part in evaluating database updating needs. Evira also analyses the foods, in order to update the outdated information and produces missing analytical data, in Fineli.

\subsection{Matís - Icelandic Food and Biotech R\&D, Iceland}

Matis is an Icelandic Food and Biotech R\&D institute, governmentally owned, with about 100 employees. The role of Matís is to increase the value of food processing and 
food production, through research, development, dissemination of knowledge and consultancy, as well as to ensure the safety and quality of food and feed products. Matís runs analytical services for industry and research projects within the Institute. Measurements of major nutrients (protein, fat, fatty acids, minerals, trace elements) and contaminants are carried out. The laboratory is a reference laboratory for certain contaminants and microbes.

Matís maintains the Icelandic Food Composition Database (ISGEM), which now includes 1,260 foods, from all food groups. The structure of the ISGEM database is based on the European Food Data Standard. Matís provides food composition data for all national nutrition surveys and nutrition research. National nutrition surveys have been a driving force for the development of the database. The database has been updated for each survey and resources have been allocated for work on the database and chemical food analysis, each time.

The database is also used by the food industry and for food labelling. The data has also been used for food composition tables and nutritional software, which have been important to the public and researchers. Data is now available on the Internet (http://www.matis.is/neytendur/leit-i-isgem-gagnagrunni).

The Icelandic Food Composition Database (ISGEM) was established in 1987. Since then, compilation has been carried out in close co-operation with people working on chemical food analysis. Since 1987, the database has been hosted at three institutes with chemical food analyses having been carried out, at those institutes. Food analysis projects, for the database, have been carried out from the beginning, although there have been periods without analyses, due to a lack of financial resources.

\subsection{Mattilsynet, Norwegian Food Safety Authority (NFSA)}

The Norwegian Food Safety Authority (NFSA) is a governmental body, whose aim, through regulations and controls, is to ensure that food and drinking water are as safe and healthy, as possible, for consumers and to promote plant, fish and animal health.

Matvaretabellen is the Norwegian national food composition table maintained by the Norwegian Food Safety Authority. The Food Composition Table (FCT) provides information concerning the content of nutrients and energy in most of the commonly consumed foods, in Norway. 1,600 food items and values for 38 nutrients are included in the FCT.

The FCT is the fundamental, basic tool for estimating energy and nutrient intake in individuals and populations. It is, therefore, an important tool in governmental food policy and management, education and public health promotion, and for health workers and researchers. The table is also used by the food industry as the basis of nutrient declarations and in food production. 


\subsection{University of Oslo (UIO), Norway}

The department of Nutrition at the University of Oslo has, for many years, been responsible for the food composition database and integrated food and nutrient calculation system (KBS) used in the Norwegian national dietary surveys. As part of this, the department of Nutrition works in close collaboration with the Norwegian Food Safety Authority regarding compilation of food composition data. In addition to being a vital tool in the national dietary surveys, KBS is also used in dietary and nutrition research and education at the University of Oslo.

\subsection{National Food Agency (NFA), Sweden}

The National Food Agency (NFA) is a governmental body under the Ministry of Enterprise and Innovation. The agency works towards following goals - healthy dietary habits, safe foods and fair practices in the food trade - through regulations, recommendations and communication.

The Livsmedelsdatabasen is maintained at the department of Risk and Benefit Assessment, where food data is compiled and published, and analysis projects are planned and reported. The work is carried out in close collaboration with the Chemistry Department, where foods are analysed.

All food information is stored in the, in-house built, computer system, Livsmedelssystemet. Livsmedelssystemet also includes web based dietary intake tools and applications for calculating the energy and nutrient content of foods and food intake. Around 2,000 foods and 59 nutrient values are included in the Swedish Food Composition Table, Livsmedelsdatabasen, which is published online, on the NFA webpage. In addition, specific foods are compiled for the national dietary surveys and other projects. In total, the Livsmedelssystemet includes over 4,000 foods.

\subsection{National Institute for Health Development (NIHD), Estonia}

The National Institute for Health Development is a government established research and development body collecting, connecting and providing reliable national information, from a multitude of sources, related to the health of the Estonian population. Its mission is to establish and share health related knowledge, as well as to influence health behaviour and determinants of health, so as to increase the wellbeing of the people in Estonia and help them live longer and healthier lives. The institute engages in public health related research and health promotion, as well as development and implementation of disease prevention programmes and activities.

NutriData is the first evidence-based Estonian food composition database. It includes information on the composition of more than 3,300 foods consumed in Estonia and maximum of 60 nutrient values per food profile. The NutriData food composition database includes information on the average energy and nutrient content of the foods 
most commonly consumed in Estonia. Starting from 2015, the content of the database is freely available, as open data. In Estonia, food composition data is mainly needed in nutrition research and dietary counseling, but also product development (mainly for small and medium sized enterprises) and for the implementation of nutritional recommendations in schools and kindergartens.

\subsection{Nordic Committee on Food Analysis (NMKL)}

The Nordic Committee on Food Analysis, NMKL, was established in 1947 and consists of chemists, microbiologists, sensory analysts and statisticians from the five Nordic countries: Denmark, Finland, Iceland, Norway and Sweden. NordVal International, which reviews and certifies proprietary methods, was incorporated into the NMKL, in 2007. There is a national committee of appointed experts in each of the Nordic countries. The General Secretariat is located at the National Veterinary Institute in Oslo, Norway. Organizationally, the NMKL is linked to the Nordic Council of Ministers.

The NMKL's objectives are to:

- Be a network of experts in food analysis.

- Provide reliable methods for foods and feeds.

- Offer NordVal certified methods for feed, food and environmental samples.

- Develop guidelines for laboratories and users of analytical results.

- Organize relevant training courses, workshops and seminars, both nationally and internationally.

- Promote Nordic interests, internationally, on topics relating to food methodology. 


\section{Activities of the Nordic Food Analysis Network between 2012-2016}

\subsection{Summary of the network activities}

The project was launched in June 2013, but the activities were started closer to the end of that year, after signing the contract. Finland (National Institute for Health and Welfare, Nutrition unit) has been responsible for the coordination. The network activities are summarized in Table 3 . The minutes of the physical meetings are presented in Appendix 1.

The Nordic Food Analysis Network activities have been based on the following corner stones:

- A shared extranet site, where the countries and institutions have shared the progress of national chemical food analysis programmes and future plans, with the other partners. This site has also been used to share meeting and presentation materials among the network.

- Face-to-face meetings were organized once a year (Helsinki, Finland 2014; Tallinn, Estonia 2015 and Gothenburg, Sweden 2016). These meetings have been a forum to update the participants on the chemical food analysis and food composition database developments, in the network countries. Analytical developments, especially on fibre, iodine and sodium determinations, as well as developments in determination of other nutrients, were presented and discussed (e.g. fatty acids, vitamin K etc.). Also, other aspects for developing the Nordic collaboration, in this area, were discussed at the meetings. Agendas of these meetings, are presented in Appendix 1.

- The network also organised an open satellite symposium, in Gothenburg, on 19 June 2016, on "A Harmonized Nordic Food Composition Database - Why not?" with about 40 participants.

- Virtual meetings and electronic questionnaires have been used to facilitate the collaboration. In addition, bilateral meetings and project meetings, at the national level, have been organized. 
Table 3: Summary of the main network activities

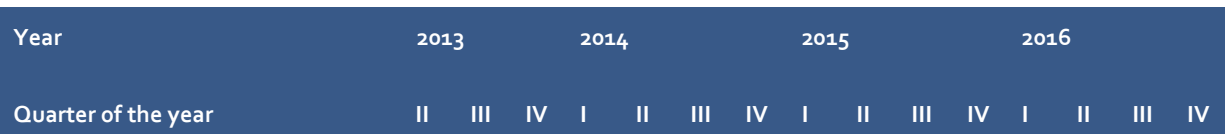

Activity of the network

Action plan created and updated

$x \quad x$

An extranet site and a web-platform

of the network launched

Food analyses plans updated \&

shared on the extranet site

Questionnaire on the activities

Virtual meetings of the network

Face-to-face meetings of the network

(Helsinki, Tallinn, Gothenburg)

Comparisons of analysed values of

Nordic foods

Public satellite symposium organized

(Gothenburg 2016)

Meeting presentations on the

activities of the network

Study protocols created and funds

applied as appropriate

$x$

Project management reporting

$x$

$\mathrm{X}$

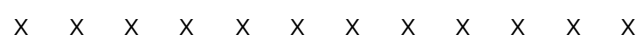

Final report compilation

$X$

$x+x$

X $\quad x$

$\begin{array}{llll} & x & x & x\end{array}$

$x$

$\mathrm{X}$

x $\quad x \quad x \quad x$

x $\quad x \quad x \quad x \quad x \quad x$

X $\quad x \quad$ X $\quad x \quad x \quad x$

$\times \quad \times \quad x$ 


\section{Nutrient analysis programmes in the Nordic countries to update the national food composition databases}

\subsection{Danish National Food Institute (DTU)}

Denmark has had an official food composition table since 1982 and data from this was the foundation of the Danish Food Databank, which is now located at the National Food Institute, at The Technical University of Denmark. Original food composition data emerging from the analytical activities of the laboratories connected to the National Food Agency, and later also to the National Food Institute, has been the primary source for new data. In the early years of the Food Composition Databank, there were great expectations for the possibility of data delivered from the Food Monitoring System running at the National Food Agency, but during the years, it became evident that monitoring data are not the ideal source of data, and a new strategy for analytical projects for food groups was initiated.

The National Food Institute separated from the Danish Veterinary and Food Administration in order to separate risk assessment and risk management collaboration for production of data. These tasks were divided between the National Food Institute and the Food Administration, which were established for this purpose.

Roughly, an analytical project runs like this: Each year new projects are suggested by National Food Institute (DTU Food) and the Food Administration:

- Projects are planned by the National Food Institute (DTU Food):

- Market research and sampling plan.

- Laboratory planning (methods and preparation).

- The plans are made in collaboration with the laboratories of the Food Administration and prioritized by the Food Administration.

- Chemical analyses are mainly done by the Food Administration's laboratories, under the supervision of the National Food Institute.

- Reporting data in collaboration that is drafted by the laboratories of the Food Administration. 


\subsubsection{Nutrients}

The samples are most often individual samples, but may be composite samples, depending on the specific food items, within the projects. Where applicable, samples are collected during different seasons. The relevant nutrients and parameters are included in the analyses (Table 4).

Table 4: Nutrients covered by chemical analyses of the Danish National Food Institute

Proximates: Fat, protein (nitrogen), dry matter, ash

Fatty acids

Carbohydrates (glucose, fructose, galactose, lactose, maltose, sucrose)

Total dietary fibre

Fat soluble vitamins $(A, D, E)$

Water soluble vitamins $\left(B_{1}, B_{2}, B_{6}\right.$, niacin, folate, $\left.B_{12}, C\right)$

Trace elements ( $\mathrm{Cl}, \mathrm{Na}, \mathrm{Ca}, \mathrm{Mg}, \mathrm{P}, \mathrm{Fe}, \mathrm{Cu}, \mathrm{Zn}, \mathrm{Mn}, \mathrm{Se}, \mathrm{Ni}, \mathrm{I})$ and occasionally trace elements from this group ( $\mathrm{S}, \mathrm{Cr}, \mathrm{Mo}$ $\mathrm{Co}, \mathrm{Ni}, \mathrm{F}, \mathrm{Si}, \mathrm{Rb}, \mathrm{Al}, \mathrm{B}, \mathrm{Br}$ )

Source: The work is funded by the Ministry of Food, Agriculture and Fisheries.

\subsubsection{Analysis projects during the last 15 years}

Chemical food analysis projects are listed in Table 5 .

Table 5: Analysis projects during the past 15 years in Denmark

$\begin{array}{ll}\text { Year } & \text { Area } \\ 2002 & \text { Vitamin D in milk, bread } \\ 2003 & \text { Baby foods, fast food, biscuits, tap water } \\ 2004 & \text { Food in work place canteens, dairy products, trans fats } \\ 2006 & \text { Bottled water } \\ 2007-08 & \text { Baby foods } \\ 2007 & \text { Fish } \\ 2008 & \text { Beverages, gluten, dairy products } \\ 2008-2009 & \text { lodine and salt in bread } \\ 2009 & \text { Fish, fruit and vegetables, minced meat, lunch in school } \\ 2010 & \text { Baby foods, beverages, trans fatty acids, eggs } \\ 2011 & \text { Delicatessen (cold cut), meat, chicken, sweets and candy, market analysis } \\ 2012-14 & \text { Milk and dairy models } \\ 2014-16 & \text { Bread and bread products } \\ 2014-15 & \text { Food in work place canteens } \\ 2015-16 & \text { Delicatessen (cold cut) } \\ 2014-16 & \text { Breakfast cereals } \\ 2015-16 & \text { Pork }\end{array}$

\subsubsection{Plans for the future}

In connection with cutbacks at the Danish Veterinary and Food Administration and their laboratories, future work has been discussed during 2016 and will undergo reorganisation, beginning in January 2017. 


\subsection{National Institute for Health and Welfare (THL), Finland}

Before 2012, continuous funding for an analytical programme did not exist in Finland and the opportunity to carry out analysis was solely dependent on the possibilities to compete for grants. Analysed nutrient values, in the national food composition database, have been analysed by the laboratories at the University of Eastern Finland, the University of Helsinki and the University of Turku, as well as at Agrifood Research Finland and the Finnish Food Safety Authority Evira.

\subsubsection{Analysis projects during the last 15 years}

The National Food Analysis programme was launched in 2012. The main objective of this programme is to obtain new analytical data about foods that are important from the perspective of Finnish food and nutrition policy. With regard to food policy, requirements for the mandatory nutrient declaration (EU 1169/2011) were taken into account. From a nutrition point of view, fatty acids, fibre, vitamin $D$ and iodine were specifically prioritised. The programme closely co-operates with universities and research institutes, in order to include food composition analysis in the other ongoing food chemistry research projects. The priorities of the national analysis programme are set by the steering group of the Finnish Food Composition Data, which has representatives from governmental authorities and universities to food industry and food trade. Although some governmental funding has been available for this programme, funding of the programme is a continuous challenge (Table 6).

Samples were collected, according to their market shares, from major wholesale food chains, in Finland, and analysed as a composite sample. The selection of food items was based on shelf-metres, which is a good indicator of the market share of the product. Usually, 12 subsamples were pooled to form a composite sample. Occasionally, especially if the food in question is not generally available at retail stores, samples were bought from ethnic food stores, market places or market halls.

The first objective, of the chemical food analysis programme, was to update the analytical data of meat, fish and eggs. The main focus was the fatty acid composition, with proximates and minerals, including sodium, also being analysed. Vitamin $D$ and iodine were also analysed for fish.

The second objective was to update the analytical data of cereals, legumes, berries, mushrooms and edible seeds. The main focus was on commercially important plant foods, e.g. funnel chanterelle, which does not have sufficient nutrient content data in order to declare the mandatory nutrient content on labels. Proximates, minerals, sugars, fibre, folate and vitamins $C_{1} B_{1}$ and $B_{2}$ were analysed. In addition, vitamin D from mushrooms and fatty acids from edible seed were analysed.

Adequate iodine intake is a major concern in Finland. In recent decades, there have been changes in the iodine fortification of feed and as a result, there was a need to update the iodine content data of milk products and eggs. The latest iodine analyses had been done in the late $1980 \mathrm{os}$. Organic products were also included in the current study. lodine was analysed by inductively coupled plasma mass spectrometry (ICP-MS). 
According to the nutrient declaration (EU 1169/2011), salt is calculated by multiplying the total sodium content by 2.5 , which means that both natural and added sodium will be taken into account. As a result, there was a need to update the natural sodium content of basic foods. Sodium was analysed from almost all basic food items included in the chemical food analysis programme.

The fibre definition, currently in use, in the nutrient declaration (2008/100/EC) was changed in 2008. Unfortunately, there has not been sufficient new fibre content data that correspond to the new definition. The Finnish Food Safety Authority Evira uses the fibre analysis method (AOAC 2011.25), which analyses all the dietary fibre components included in the new dietary fibre definition. The disadvantage of the method is that it is time-consuming. Therefore, only important cereals, legumes, vegetables, fruits and seeds have been included in the analyses, so far.

Folate analysis of cereals and breads is an ongoing analysis project at the University of Helsinki. The main focus is on yeast and lactic acid fermented breads, and on malted breads. Fermentation and malting are supposed to elevate the folate content of breads.

The second ongoing project is the analysis of edible seeds. The eating of edible seeds is encouraged in the nutrition recommendation (Nordic Council of Ministers 2014, Valtion ravitsemusneuvottelukunta 2014), however, there is still insufficient nutrient content data. The seeds selected for analysis are sunflower seed, linseed, pine nut, chia seed, poppy seed and hemp seed. Proximates, fatty acids, fibre, minerals and vitamin E will be analysed.

Table 6: Analysis projects during the past 15 years in Finland

\begin{tabular}{|c|c|}
\hline Year & Area \\
\hline $2009-2010$ & $\begin{array}{l}\text { Trans fatty acids in biscuits, ice creams, whipping creams, French fries, popcorn, deep frozen doughs, } \\
\text { infant formulas and baking margarines. } \\
\text { Nitrates and heavy metals in vegetables, meat products, sausages and cheeses. } \\
\text { Vitamin D in eggs, poultry. }\end{array}$ \\
\hline $2011-2013$ & Fatty acids in human milk. \\
\hline 2012 & Trans fatty acids in margarines and fat spreads, and breakfast cereals. \\
\hline 2012-2014 & $\begin{array}{l}\text { Fatty acids, vitamin D, proximates, iodine, minerals in Baltic herring and cultivated salmon (Finnish and } \\
\text { Norwegian). }\end{array}$ \\
\hline $2013-2014$ & Fatty acids, proximates, minerals in meat and meat products and eggs. \\
\hline $2013-2015$ & lodine in milk, eggs, cheese and human milk. \\
\hline 2014 & $\begin{array}{l}\text { Proximates, minerals, sodium, iodine, fibre, starch, sugars, fatty acids, vitamin C, folate, vitamin B1 } \\
\text { and B2 and vitamin D in grain products, fish, seaweed, vegetables, berries, mushrooms, legumes and } \\
\text { seeds. } \\
\text { Bioactive substances in Norths Carelian plants. } \\
\text { Folate, niacin, vitamin B2 in gluten free grain products. }\end{array}$ \\
\hline $2015-2016$ & Minerals, fibre, protein and total fat in several foods. Folate in grain, bread and legumes. \\
\hline $2016-$ & Fibre, minerals, heavy metals, fatty acids, total fat, protein, ash and moisture in seeds. \\
\hline
\end{tabular}




\subsection{Icelandic Food and Biotech R\&D, Matís}

All work at Matis is carried out within projects. Work on the database is part of an ongoing project that is currently under minimum activity, as the project receives no funds outside of Matís. Some financial resources are allocated to chemical food analysis, however, funding is now so limited that only a few analyses can be carried out each year, and these have currently been relegated to data checking. Applications are sent to R\&D funds; however, the possibilities of receiving financial support from these funds, for food composition projects, are not great. Nonetheless, a few food composition projects have been supported in the past.

\subsubsection{The analysed nutrients}

Analyses for food composition projects are carried out at Matis. The following components are analysed: protein, fats and fatty acids, minerals ( $\mathrm{Na}, \mathrm{Mg}, \mathrm{P}, \mathrm{K}$ and $\mathrm{Ca}$ ) and inorganic trace elements (e.g. $\mathrm{Fe}, \mathrm{Cu}, \mathrm{Zn}$ ).

Dietary fibre, starch, sugars and vitamins are not analysed at the Matís laboratories. Samples, for the analysis of these components, are sent abroad, usually to companies in Germany, Sweden or Denmark. The number of samples sent for analysis is usually low, as analytical work is expensive. The samples may be either composite or individual. The variability of nutrients, due to season, region and other factors, are studied when relevant and financially possible.

\subsubsection{Analysis projects during the last 15 years}

Chemical food analysis projects are listed in Table 7. The fatty acid project was a part of the recent national nutrition survey. The barley project dealt mainly with quality aspects, but, gave important composition data. During the 2002 to 2008 period, database analyses were carried out on a small scale. R\&D food processing and quality projects gave some food composition data. Examination reveals that the foods that were analysed in the R\&D projects were not necessarily the most important foods in the database. In the period of 1980 to 1990 , several food analysis projects were carried out for the Icelandic Food Composition Database. The data obtained during this period remains an important part of the database. 
2008-2009 Inorganic trace elements ( $\mathrm{Se}, \mathrm{Hg}, \mathrm{Fe}, \mathrm{Cu}, \mathrm{Zn}$ ) and minerals in dairy products and meat

2008-2011 Fish (macronutrients, inorganic elements and fatty acids)

2008-2011 Processed foods (fatty acids)

2010-2011 Barley grown in Iceland

$2012 \quad$ Proximates in lumpfish (Cyclopterus lumpus)

2015 Proximates and minerals in various samples from a Total Diet Study. Proximates in barley from Iceland, N-Norway, Orkney and Newfoundland.

2016-2017 Fish (macronutrients, inorganic elements and fatty acids)

\subsubsection{Current analysis projects}

A new project on the nutrient composition of fish was started in 2016. The project is carried out in co-operation with seafood companies and is financed by the Association of Icelandic Fisheries.

\subsubsection{Plans for the future}

Discussions are currently underway with the ministries to provide support for the infrastructure, including food composition, food safety and nutrition surveys. If these efforts succeed, it will be possible to carry out work and analyses for the ISGEM database. Until the database is financially supported, work will be kept at a minimum, and will mostly involve responses to inquiries. Some work will be devoted to applications of food composition.

\subsection{Norwegian Food Safety Authority (NFSA)}

Norway has launched a new food composition table online (May 2016) with updated values (www.matvaretabellen.no). The Norwegian Food Safety Authority includes at least one chemical food analysis project, each year. The Norwegian Food Safety Authority also collaborates with the food industry and uses food quality analyses from the food industry in the Food Composition Table. Commonly eaten foods and food produced in Norway are prioritized, however, as there has been an increase in imported food items, these will now be included. Statistics from the latest national dietary survey are exploited in order to find out the relevant foods to be analysed. Together with the University of Oslo, the Norwegian Food Safety Authority is responsible for the Food Composition Table together with the University of Oslo. 


\subsubsection{The analysed nutrients}

The concentrations of all of the nutrients mentioned in the Norwegian dietary recommendations are included in the analyses. Some additional analyses can be done if needed, for example, while analysing the fatty acid content of margarines. The samples may be composite samples or individual samples, depending on whether the information about variation is relevant or not. Whenever necessary, the samples can be collected during different seasons.

Table 8: Nutrients covered by chemical analyses of the Norwegian Food Safety Authority

\section{Nutrients}

Macronutrients

Fatty acids and cholesterol

Carbohydrates (glucose, fructose, maltose, lactose, sucrose)

Fibre

Fat soluble vitamins and vitamin-like compounds ( $A, D, E, K$, carotenoids)

Water soluble vitamins ( $B 1, B 2, B 6$, niacin, folate, $B 12, C)$

Trace elements ( $\mathrm{Ca}, \mathrm{Fe}, \mathrm{Na}, \mathrm{K}, \mathrm{Mg}, \mathrm{Zn}, \mathrm{Se}, \mathrm{Cu}, \mathrm{P}$ and I)

\subsubsection{Analysis projects during the last 15 years}

During the last 15 years, the focus has been on different meats, fishes and white wheat flour. Some of the reports describing the analysis project and the results are available on the NFSA website (http://www.mattilsynet.no). The chemical food analysis projects are listed in Table 9.

Table 9: Analysis projects during the past 15 years in Norway

\begin{tabular}{ll} 
Year & Area \\
2001 & Miscellaneous foods (fruit, vegetables, pasta, poultry) \\
2002 & Ready dishes (pasta, liver, fast food, pizza, rice, cakes) \\
2003 & Breakfast cereals, cakes, biscuits, oil \\
2004 & White wheat flour \\
2004 & Meat products \\
2006 & Cold cuts (meat) \\
2007 & Fish \\
$2007-2008$ & Trans fatty acids \\
2008 & Pork \\
2009 & Lamb and beef \\
2011 & Milk and milk products* \\
2012 & Baby porridge \\
2013 & Tex-mex products \\
2014 & Chips and salty nuts \\
2015 & Frozen Pizza Fish products \\
2016 & Chicken and eggs \\
2017 & Bread, breakfast cereals and crispbread \\
2018 & Vegetables \\
\hline
\end{tabular}

Note: *Analysis projects from the food industry 


\subsubsection{Current analysis projects}

In 2016, Norway analysed eggs and chicken samples.

\subsubsection{Plans for the future}

In 2017, NFSA will be analysing bread, breakfast cereals and crispbread, and is planning to analyse the most consumed vegetables in 2018. In addition to nutrients, heavy metals and occasionally other contaminants will also be analysed.

\subsection{Swedish National Food Agency (NFA)}

The Swedish Food Composition Database is further developed by annual analysis projects, with approximately 30 analysed foods per year. Each analysis project requires about 3 years to complete, including planning, the actual analysis and the final report. A plan is made 1 year before the actual analysis.

Commonly eaten foods with outdated data are prioritized. Statistics from the latest national dietary survey, Riksmaten 2010-2011, have been exploited in order to determine the relevant foods to be analysed. 320 foods, that contribute to more than $75 \%$ of the nutrient intake in Sweden, were identified as such "key foods" (LundbergHallén and Öhrvik, 2015). Sampling of the key foods is performed based on consumption statistics, for each food. The planning, sampling and compiling is carried out at the Risk and Benefit Assessment Department. The team collaborates closely with the Chemistry Department at the National Food Agency (NFA), which is in charge of the chemical analysis, and where micronutrients (vitamins and metals) and fatty acids are determined. They are also actively in contact with the food industry and food producers.

\subsubsection{The analysed nutrients}

The focus of the chemical analyses is on the determination of the nutrients mentioned in the Nordic recommendations (the Nordic Council of Ministers 2012). Some additional analyses are also carried out. The samples may be composite samples or individual samples, depending on whether the information about variation is relevant or not. The samples are collected during different seasons, whenever necessary. 


\subsubsection{Analysis projects during the last 15 years}

The annual analysis projects focus on certain foods or food groups, each time. Reports describing the analysis projects and the results are available on the NFA website (www.slv.se). Chemical food analysis projects are listed in Table 11.

\section{Table 11: Analysis projects during the past 15 years in Sweden}

$\begin{array}{ll}\text { Year } & \text { Area } \\ 2001 & \text { Mixed products } \\ 2002 & \text { Fast food and mixed products } \\ 2003 & \text { Snack foods (for the child dietary survey) } \\ 2004 & \text { Food for the child dietary survey } \\ 2005 & \text { Dairy products, vegetarian meals } \\ 2006 & \text { Sauces and aloe vera } \\ 2007 & \text { Moose meat, fat quality } \\ 2008 & \text { Eggs, beans, whole meal products } \\ 2009 & \text { Potatoes, margarines } \\ 2010 & \text { Fish, berries, industrial margarines } \\ 2011 & \text { Meat from wild animals, reindeer, oils } \\ 2012 & \text { Oils } \\ 2013 & \text { Vegetables and root vegetables } \\ 2014 & \text { Fruit and vegetables, beverages } \\ 2015 & \text { Meat and deliproducts }\end{array}$

\subsubsection{Current analysis projects}

During 2016, Swedish analyses focused on cereals and dairy products. Foods are purchased from stores or supplied by dairy companies.

On-going and planned analyses include:

- Cereals, i.e. crispbread (generic, rich in fibre), crispbread (generic), loaf (rich in fibre, marked with the Keyhole symbol), bake-off white baguette, Rallarhalvor (dark rye bread), sourdough bread/levain, oats, oats with added fibre, breakfast cereals such as Special K, breakfast cereals such as Allbran, muesli with berries, muesli with nuts, gingerbread, dark bread gluten free, white bread gluten free, bake-off bread gluten free, spelt flour, almond flour, buckwheat flour, potato flour and corn flour. 
- Dairy, i.e. cheese $28 \%$, cheese $28 \%$ organic, cheese $31 \%$, brie cheese, mozzarella, halloumi, feta cheese, ice cream cone (aggregate), ice cream from a package (aggregate), pancakes, cheese cake, sour milk $3 \%$ (summer), sour milk $3 \%$ organic (summer), sour milk 3\% (winter), yoghurt 10\% (winter), yoghurt 10\% (summer), yoghurt $3 \%$ organic (summer), yoghurt $3 \%$ (summer), yoghurt $3 \%$ (winter), quark, quark drink and yoghurt drink.

\subsubsection{Plans for the future}

The focus for future analyses will be on the key foods identified in the latest dietary survey, Riksmaten Adolescents 2016-17. The NFA is keen to collaborate with the Nordic countries on future nutrient analyses.

\subsection{National Institute for Health Development (NIHD), Estonia}

The evidence-based food composition database, created by the National Institute for Health Development (NIHD), was created in the early 1990s, with Micronutrica software for menu analysis that was acquired from the Finnish National Institute for Health and Welfare. Over the years, the list of foods in Micronutrica has been supplemented with data on local foods. In 2009, the database was restructured to meet the requirements of Eurofoods and EuroFIR, and data updating was started. In 2010, the NutriData database was made public and accessible on the web.

The majority of the food composition data has been collected from different literary sources, international food composition databases, the food industry and via direct chemical food analyses. Much of the data has also been obtained via recipe calculation systems. As for enhancing the quality of the food composition data, by 2015, a data input platform was created for use by food industry representatives and research organizations for more efficient data exchange and management. Hopefully, it will enhance, both, the speed of data renewal and data quality.

The administrators of the NutriData information system (including the FCD) are currently working on moving the needs of the NutriData system higher up on the priority list within the Institute (as well as the department) in order to move it out of the "side-project" phase and help enable the system to reach its full potential. If successful, the NutriData food composition database would also benefit.

\subsubsection{Analysis projects during the last 15 years}

Estonia has not had, and does not currently have, a set plan for chemical food analysis, mostly due to limited resources in terms of people, time and finances. However, there is a strong need for such a plan, and when the needs of the NutriData system become more relevant within the Institute, the annual chemical food analysis projects should also come to life. 
Up to this point, the National Institute for Health Development has conducted two chemical food analysis projects: the first analytical project was conducted in 2009 and the second one, in 2011 (Table 12). A great deal of valuable input, in terms of future chemical food analyses, is expected from the results of the recent national dietary study, which ended in 2015.

Table 12: Chemical food analysis projects conducted by National Institute for Health Development

\begin{tabular}{|c|c|c|c|}
\hline Laboratory & Year & Foods & Nutrients \\
\hline $\begin{array}{l}\text { The Central Veterinary and } \\
\text { Food Laboratory }\end{array}$ & 2011 & $\begin{array}{l}\text { Bread, kama, kefir, } \\
\text { quark, pork, Baltic } \\
\text { herring }\end{array}$ & $\begin{array}{l}\text { Full nutrient profile (macronutrients, carbohydrates, } \\
\text { fatty acids, vitamins, minerals), including some } \\
\text { invalid results }\end{array}$ \\
\hline $\begin{array}{l}\text { Health Board Laboratory, } \\
\text { Agricultural Research Centre } \\
\text { Laboratory }\end{array}$ & 2009 & $\begin{array}{l}\text { Rye bread, milk, sour } \\
\text { cream }\end{array}$ & $\begin{array}{l}\text { Almost full nutrient profile (macronutrients, } \\
\text { vitamins, minerals, fatty acids), including some } \\
\text { invalid results }\end{array}$ \\
\hline
\end{tabular}





\section{Comparability of nutrient values of foods and fortification programmes in the Nordic countries}

\subsection{Dietary fibre, iodine and salt}

\subsubsection{Background and aim}

lodine, sodium and dietary fibre (DF) levels in food are momentous nutrients for several reasons. Mild iodine deficiency occurs in the Nordic Countries and fortification practices differ. Quantification of salt in food is, today, based on sodium concentrations instead of chloride, and policies to lower salt intake in the Nordic Countries, vary. The definition of dietary fibre has been revised recently and new methods have been developed to meet the definition. The aim of this work was to determine the contents of iodine, sodium and DF in selected foods and compare the results of the countries participating in The Nordic Food Analysis Network. The detailed results of the dietary fibre analyses have been published (Rainakari et al. 2016) and the iodine and sodium results were presented at the Nordic Nutrition Conference, in June 2016 (Pastell et al. 2016).

\subsubsection{Materials and methods}

Samples of whole milk, conventionally produced eggs, organic eggs, low-fat cheese, white wheat bread and farmed salmon (Salmo salar) were collected from Estonia, Finland, Iceland, Norway and Sweden for iodine and sodium analyses. Similar sample collections of rye flour, wholegrain wheat flour, rolled oats and carrots for DF analyses, were carried out in Estonia, Finland, Iceland, Norway and Sweden. The sample collections were based on the supply and the market shares of each country.

Twelve subsamples of each food were purchased, pooled to composite samples and sent to Evira for analysis. lodine was analysed using ICP-MS (inductively coupled plasma mass spectrometry), sodium by the ICP-OES (inductively coupled plasma optical emission spectrometry) technique, and the DF contents using the AOAC 2011.25 method. In the DF method, the total DF amount is the sum of gravimetrically determined water-insoluble (IDF) and water-soluble polysaccharides (SDFP), and chromatographically determined oligosaccharides (SDFS). The sampling protocol is presented in Appendix 2. 


\subsubsection{Results and conclusions}

The iodine contents in Icelandic whole milk and conventionally produced eggs, as well as in Swedish organic eggs were two-fold, compared with the respective foods in other countries (Table 13). Small differences were also detected in sodium contents of edamtype, low-fat cheese and white wheat bread. One fifth more sodium was found in Estonian and Icelandic cheese, as well as in Icelandic wheat bread (Table 14).

Table 13: lodine contents $(\mu \mathrm{g} / 100 \mathrm{~g})$ reported as fresh weight in the selected foods

\begin{tabular}{llrrrrr} 
Country & $\begin{array}{l}\text { White wheat } \\
\text { bread }\end{array}$ & $\begin{array}{r}\text { Cheese } \\
\text { (17\% fat) }\end{array}$ & Eggs & $\begin{array}{r}\text { Eggs } \\
\text { (organic) }\end{array}$ & $\begin{array}{r}\text { Whole milk } \\
\text { (3\% fat) }\end{array}$ & $\begin{array}{r}\text { Farmed } \\
\text { salmon }\end{array}$ \\
\hline Estonia & n.d. & 27 & 43 & - & 19 & - \\
Finland & n.d. & 25 & 37 & 32 & 17 & 8 \\
Iceland & n.d. & 24 & 73 & - & 37 & 9 \\
Norway & n.d. & 19 & 30 & 30 & 16 & 9 \\
Sweden & n.d. & 17 & 42 & 61 & 13 & $<6$ \\
\hline
\end{tabular}

Table 14: Sodium contents $(\mathrm{mg} / 100 \mathrm{~g})$ reported as fresh weight in the selected foods

\begin{tabular}{lrrr} 
Country & White wheat bread & $\begin{array}{r}\text { Cheese } \\
(\mathbf{1 7} \% \text { fat })\end{array}$ & Eggs \\
Estonia & 467 & 578 & 147 \\
Finland & 449 & 449 & 139 \\
Iceland & 549 & 568 & 143 \\
Norway & 459 & 443 & 135 \\
Sweden & 418 & 484 & 142 \\
\hline
\end{tabular}

Some variation was also found in the total DF contents of wholegrain wheat flour, where the differences were mainly dominated by the water-insoluble DF fraction (Table 15). The DF contents of the analysed cereal products were higher than those previously reported in the Food Composition Databases due to the new method that was used, where the oligosaccharides were analysed differently from earlier methods. Rye flour and wholegrain wheat flour were high in oligosaccharides (SDFP), which can essentially explain the higher results, in these cereals. The total DF content of carrots was 2.4-2.9 $\mathrm{g} / 100 \mathrm{~g}$ as fresh weight, which is similar to values presented in the FCDBs.

The contents of iodine, sodium and DF are not equal in all foods among Nordic Countries and Estonia. Differences in animal feeding practices produce true compositional differences in foods. Borrowing data from food composition databases from even neighbouring countries should be done with caution. 
Table 15: Dietary fibre contents analysed as IDF, SDFP and SDPS fractions and total DF in dry weight $(\mathrm{g} / 100 \mathrm{~g})$ from cereals and carrot $(\mathrm{DF}=$ dietary fibre, IDF = water-insoluble polysaccharides, SDFP = water-soluble polysaccharides, SDFS = oligosaccharides)

\begin{tabular}{|c|c|c|c|c|c|}
\hline Country & IDF & SDFP & SDFS & Total DF & Moisture (\%) \\
\hline \multicolumn{6}{|c|}{ Rye flour (g/100 g, dry weigh) } \\
\hline Estonia & 11.0 & 4.0 & $4 \cdot 3$ & 19.3 & 11.5 \\
\hline Finland & 10.5 & 4.0 & $5 \cdot 5$ & 20.1 & 11.0 \\
\hline Norway & 10.2 & 3.9 & 4.9 & 19.0 & 11.6 \\
\hline Sweden & 11.5 & 4.2 & $4 \cdot 3$ & 20.0 & 11.8 \\
\hline \multicolumn{6}{|c|}{ Wholegran wheat flour ( $g / 100 \mathrm{~g}$, dry weigh) } \\
\hline Estonia & 8.7 & 2.6 & 1.9 & 13.2 & 11.4 \\
\hline Finland & 7.2 & 1.1 & 1.9 & 10.2 & 11.0 \\
\hline Norway & 11.4 & 2.0 & 2.2 & 15.6 & 11.6 \\
\hline Sweden & 10.6 & 2.2 & 2.9 & 15.7 & 12.8 \\
\hline \multicolumn{6}{|c|}{ Rolled oats (g/100 g, dry weigh) } \\
\hline Estonia & 6.7 & 5.6 & 0.3 & 12.6 & 10.2 \\
\hline Finland & 6.8 & 4.8 & 0.5 & 12.1 & 9.7 \\
\hline Norway & 8.1 & 3.7 & 0.2 & 12.0 & 10.9 \\
\hline Sweden & 6.9 & 3.9 & 0.2 & 11.0 & 10.7 \\
\hline \multicolumn{6}{|c|}{ Carrot (g/100 g, dry weigh) } \\
\hline Estonia & 19.6 & 3.8 & 0.5 & 23.9 & 87.9 \\
\hline Finland & 14.7 & 5.1 & 0.5 & 20.2 & 88.0 \\
\hline Norway & 19.8 & 2.5 & 0.5 & 22.8 & 88.6 \\
\hline
\end{tabular}

\subsection{Differences due to fortification programmes}

One reason for the differences in the nutrient values of foods between the Nordic countries is the different food fortification programmes used in the individual countries. To gain a better understanding of this issue, the network collected data via a questionnaire sent to the partners concerning selected fortification programmes, in use, in the Nordic countries prior to the second physical meeting, held in June 2015. Estonia was excluded from this data collection, as no national fortification programmes exist in Estonia. The data was further updated, later during the project. The compiled information is shown in Appendix tables 3.1 and 3.2.

The results showed that differences in fortification practices are a partial reason for the inconsistent food composition of equivalent foods, in the Nordic countries. The main differences are seen in vitamin $\mathrm{D}$ composition and iodine. 



\section{Towards improved Nordic co-operation - What do we need to succeed?}

\subsection{Improved coordination}

In order to work together successfully, we need better coordination at several stages of the co-working process. First of all, we have to divide the tasks among several compilers and collaborate on sampling plans. This is especially important when planning the analyses of imported foods, e.g. fruits and vegetables. It is a good idea to share information about suitable laboratories that are specialised in specific tasks. We should also keep a record of all of the laboratories capable of carrying out analyses of certain nutrients, e.g. fibre, carbohydrates, vitamins, as well as share the information on who collaborates with which laboratories, in order to carry out the specific analyses. Above all, we need to have someone who creates and updates the shared information from relevant laboratories and keeps up with current knowledge.

\subsection{Facilitating data sharing}

The obvious aim of the Nordic co-operation is to enhance and empower the analysis processes by avoiding overlapping analyses and by strengthening the flow of information between participants. The main interest is to analyse new foods, including the industrial products as well as the products and the ingredients used by catering kitchens.

Data for the industrial ingredients often includes old data and data gaps that result from the inadequate quality of the industry databases. Moreover, small producers often do not have the resources to analyse their own raw ingredients, so it is very important to have up-to-date data in the food composition databases, available for all.

Other foods that should be prioritised are the products for the specific groups, e.g. vegetarian dishes or foods used by different ethnic groups. During the discussion, it was also proposed that raw ingredients should be prioritized over dishes.

Modern web based communication platforms are available and can be used for sharing the information and archiving the results concerned with the analysis processes. The importance of the maintenance of the information content of the platform, as well as keeping the communication, discussion and information flow going between participants is, however, very important to gain from these tools. Such a platform would optimally to be constructed and maintained by persons who are 
experienced in considering the whole process, and from both a nutritional and toxicological point-of-view.

\subsection{Nordic networking - valuable peer-support}

The community of chemists and compilers of food composition databases has become smaller during the past decades. Today, only a handful, in some countries only 2-3 experts, are responsible for updating the values of the national food composition databases and chemical analyses may be outsourced, which may result in a greater need for analytical competence in the ordering and evaluating of the analytical results. In this situation, the Nordic network in this field, has proven to provide valuable peer-support to the responsible national experts. Even the main focus in the national activities, sharing ideas, plans and results can well stimulate progress, at the national level.

\subsection{Future challenges in chemical food analyses}

When it comes to foods to be analysed, it is important to carry out the analyses on all of the important nutrients. Do the participants agree upon what those important nutrients are and how does the selection of those relevant nutrients vary from food to food? Altogether, the relevant nutrients to be analysed should be unambiguously defined. Another important issue, is to consider ways of including the information about seasonal variation in the data, whenever possible. It should also be taken into consideration that some foods set special demands on the analysis process, e.g. fat content varies according to the size of the fish. It is important to be fully aware of the differences in food composition due to differences in preparation methods, raw ingredients used or fortification between the countries. In order to avoid these difficulties, open and continuous discussion is required.

From a toxicologist's point of view, certain risk-benefit analyses of the foods are relevant. A major difference between chemical analyses for food composition databases and occurrence data analyses for food control or risk assessment is the sampling of foods (Greenfield \& Southgate 2003, Finnish Food Safety Authority Evira 2015, Nordic Committee on Food Analysis 2014). While it is optimal to have representative sampling for the analysis of the nutrient content of foods, sampling for occurrence data is often risk-based. To provide useful data for risk-benefit analyses, this issue needs to be further elaborated.

Limited resources for chemical food analyses have become a major limitation for most of the Nordic countries in order to keep up with important food analysis programmes. During the network activities, different ways to rationalise the analysis work in the Nordic countries, have been discussed. The idea of specialisation in food analysis in the different Nordic countries, i.e. all Nordic countries collecting samples in a comparable way and a central laboratory for a certain nutrient serving as the analysis 
site for the selected nutrient(s), has been brought up, but has been challenged as unrealistic. This could make the work even more vulnerable. There is a common interest in maintaining a national competence and capacity for food analysis, in order to maintain a critical mass on a Nordic basis within the area of food composition information. Standardization and harmonization of sampling procedures, which would enable increased data sharing along with developmental collaboration for more efficient analytical methods, could be possible solutions for the more efficient use of resources.

\subsection{Nordic training and capacity building}

Joint Nordic training in chemical food analyses and in compilation and managing food composition databases could help in harmonising the Nordic food composition data. The idea of a food composition database compiler's "driver's licence" has been suggested in the past and could be a useful aim for the Nordic countries, after further elaboration. Several areas exist, where such capacity building efforts could be carried out in the Nordic countries, in co-operation with the Nordic Committee on Food Analysis, NMKL (see Section 2.9.).

\subsection{Becoming visible - disseminating results}

During this project, the dissemination aspects have also been discussed. The following ideas have been suggested for future initiatives and also partly applied during this project:

- The organizing of local seminars and participation in Nordic and international conferences by giving presentations and organizing satellite symposiums.

- The writing of articles that could be translated in every country, for a broader network and greater range of stakeholders.

- The planning and carrying out of projects and participation in projects that would have a strong dissemination component incorporated into them.

- Creation of a Nordic newsletter in the field to maintain networking and to inform the stakeholders as to what is happening in the Nordic food composition database field.

- Provision of more open food composition data to the broad group of data users, from consumers to scientists.

- Provision of information to the food industry, especially the SME's about the possibilities of analysed and compiled food composition data to facilitate the compilation of food labels.

- The formation of a Nordic steering group of food composition databases for leadership in the field, at the regional level. 


\subsection{Thinking outside the box - A common Nordic food composition database}

The Nordic chemical food analysis work and management of food composition databases have strong national mandates. This may even attenuate interest in trying to achieve common Nordic goals in the area. To activate discussions, this network project organised an open satellite symposium in Gothenburg on 19 June 2016 (Appendix 1 C), and gave a presentation at the Nordic Nutrition Conference on the topic of a potential goal to form a common Nordic Food Composition Database (Valsta 2016). This idea proved not to be new. It had actually been suggested, by a few pioneers in the field, in the 1980s.

Today's information technology, however, provides several new options for closer collaborations between the institutions managing the national food composition databases, including:

- Exploiting the Internet for distribution of work over organizational boundaries.

- Using modular and Web based software.

- Using interfaces that integrate information systems in different organizations.

- Using instant messaging and other tools for computer-supported co-operative work needed in activities divided between several organizations.

Challenges for a closer collaboration or even a common or a "virtual" Nordic food composition database could be seen in the recent diverging developments in the infrastructures of food information. In addition, the diversity of the nutrient composition in equivalent foods is often real, as shown in the comparison analyses organized by this network project (see Chapter 5). This is sometimes due to a divergence in fortification practices or in the composition of animal feeds, which results in differences in nutrient values.

The outcome of the discussions on this topic was a recommendation to focus on the future instead of forming any new food composition data organisations or institutions and the furthering of the harmonization of the Nordic food composition data. There are still several steps to take before the Nordic food composition data can be proclaimed as being fully comparable. 


\section{Conclusions}

Considering the vast and important uses of food composition information, the quality of this data is of great importance. In recent years, each Nordic country has, more or less, faced problems on its own, when it comes to finding resources that are needed for continuously carrying out analyses on an adequate scale. Is does not matter whether the challenge is finding financial funding for the analyses or if that problem is somewhat secondary, as there is not enough personnel to perform the mandatory tasks. However, one way or another, each national compiler team has to find a way to gain access to upto-date analytical data, in order to assure the quality of the database, in the long run. That is why the idea of a functional co-operation is very welcomed by all of the Nordic countries; however, the question is how to get the ball rolling?

This report provides information about the analytical history beginning 15 years ago and the current state of analyses, on a national level. This kind of information is very useful as every compiler team can keep this information in mind, while planning their own future analyses. However, it is clear that the information presented in this report can only take us so far: we need to keep up with the pace and get to the stage where we are able to share essential information that is being created and updated, at every turn.

There is a continuous need for a well-structured and simple-to-use communicational platform in the future, where all the information is stored and updated. We need someone to collect the information from the participants and to update the information, when necessary. Most of all, we need every member of the network to be willing to share their information, as well as use it. We have to create the kind of environment that works for this kind of co-work. Moreover, we need everyone's continued input and open feedback, in the future, in order to develop these activities and make it work for us. The network discussions have shown a strong interest in collaborating. It is important to keep the momentum going.

This project has focused on the common needs, on a nutrient level, by updating the analysis information of two currently problematic nutrients: iodine and total dietary fibre and, to some extent, sodium (salt). In addition, the challenges for obtaining comparable data from the Nordic countries have been elaborated. 



\section{References}

Danish Act no 577of 02/06/2016 Act on voluntary fortification of foods (2016). (General acceptances for addition of vitamins and minerals to certain products (voluntary addition) (in Danish: Bekendtgørelse om tilsætning af næringsstoffer til fødevarer BEK nr 577 af 02/06/2016 Gennerelle tilladelser).

Danish Order concerning mandatory addition of iodine to salt (2014). (mandatory fortification with iodine of household salt, and salt used as an ingredient in bread and bakery products with iodine at a level of $13 \mathrm{mg}$ iodine per $\mathrm{kg}$ salt) Bekendtgørelse om tilsætning af jod til husholdningssalt og salt i brød og almindeligt bagværk m.v. BEK nr 1318 af 11/12/2014.

Eurola, M., Alfthan, G., Ekholm, P., Root, T., Suoniitty, T., Venäläinen, E-R., Ylivainio, K. (2011). Report of the Selenium Working Group (abstract in English and in Swedish). 35/2011. Published by: MTT Jokioinen. http://www.mtt.fi/mttraportti/pdf/mttraportti [Accessed on 9.12.2016].

European Commission. (2005). Regulation (EC) No. 1459/2005 amending the conditions for authorisation of a number of feed additives belonging to the group of trace elements.

European Commission. (2006). Regulation (EC) No 1925/2006 of the European Parliament and of the Council on the addition of vitamins and minerals and of certain other substances to foods.

European Commission (2011). Regulation (EC) No 1169/2011 of the European Parliament and of the Council on the provision of food information to consumers.

Finnish Food Safety Authority Evira (2015). Kemiska undersökningar för att på visa att livsmedlen överensstämmer med kraven, Eviras anvisning 17069/1. Available online: https://www.evira.fi/globalassets/tietoa-evirasta/lomakkeet-ja-

ohjeet/elintarvikkeet/kemiallinen vaatimustenmukaisuus/ eviran ohje 17069_1_se.pdf.

Greenfield, H. \& Southgate, D. A. T. (2003). Food composition data. Production, management and use., Rome, FAO Publishing Management Service. Available online: http://www.fao.org/fileadmin/templates/food_composition/images/ FCD.pdf .

Institute of Medicine. (2000). Dietary Reference Intakes for Vitamin C, Vitamin E, Selenium, and Carotenoids. Washington, DC: The National Academies Press.

doi:https://doi.org/10.17226/9810. 529 pp.

Lundberg-Hallén, N. \& Öhrvik, V. (2015). Key foods in Sweden: Identifying high priority foods for future food composition analysis. J of Food Comp and Anal, 37:51-57.

Megazyme (2013). Integrated total dietary fibre assay procedure. Including resistant starch and non-digestible oligosaccharides. AOAC Method 2009.01 \& 2011.25 and AACC Method 3245.01 \& 32-50.01. Updated format 2013. Available online:

https://secure.megazyme.com/files/booklet/k-intdf_data.pdf. [Accessed on 22.12.2016].

Ministry of Agriculture and Forestry (MMM) (2016). Rasvattomaan luomumaitoon saa jatkossa lisätä D-vitamiinia (only in Finnish). http://mmm.fi/artikkeli/-/asset_publisher/rasvattomaanluomumaitoon-saa-jatkossa-lisata-d-vitamiinia [Accessed on 9.12.2016].

National Nutrition Council (VRN) (2010). D-vitamiinityöryhmän raportti (only in Finnish). http://www.ravitsemusneuvottelukunta.fi/portal/fi/tiedotteet+ja+kannanotot/kannanotot/ [Accessed on 9.12.2016].

National Nutrition Council (VRN) (2015). Toimenpidesuositus väestön jodin saannin parantamiseksi (only in Finnish).

http://www.ravitsemusneuvottelukunta.fi/portal/fi/ravitsemussuositukset/erityisohjeet+ja+raj oitukset/ [Accessed on 9.12.2016]. 
Nordic Council of Ministers (2014). Nordic Nutrition Recommendations 2012: Integrating nutrition and physical activity (English) Copenhagen: Nordisk Ministerråd, 2014, 5. Ed. , 627 p. Nord 2014:002.

Nordic Committee on Food Analysis (NMKL) (2014). Håndbok i prøvetaking av næringsmidler (NMKL-prosedyre nr. 12, 2014). http://www.nmkl.org/index.php/nb/webshop/item/handbok-iprovetaking-av-naeringsmidlerhandbok-i-provetaking-av-naeringsmidler-nmkl-prosedyre-nr12-2014.

Norfoods 2000 project group (2002). Intake calculations of food consumption data in the Nordic countries. A comparison of food composition data, calculation factors and calculation methods. TemaNord 2002:522. Nordisk Ministerråd, Copenhagen 2002.

The Norwegian Food Safety Authority (NFSA) (2016). Berikning av vitaminer, mineraler og andre stoffer.

http://www.mattilsynet.no/mat_og_vann/tilsatte_stoffer/tilsatte_vitaminer_mineraler_og_an dre_stoffer/

Pastell H, Jõeleht A, Kielland E, Reykdal Ó, Öhrvik V, Østerholt Dalane J, Valsta L, and the Nordic Food Analysis Network (2016). Levels of iodine, sodium and dietary fibre in selected Nordic and Estonian foods. Food \& Nutrition Research 2016, 60:30961, no. P422. Available online: http://dx.doi.org/10.3402/fnr.v60.31961 [Accessed 9.12.2016]

Rainakari A-I, Rita H, Putkonen T, Pastell H. (2016). New dietary fibre content results for cereals in the Nordic countries using AOAC 2011.25 method. J Food Comp Anal 51:1-8.

Valsta L, for the Nordic Food Analysis Network (2016). A Nordic food composition database -a potential goal for the future? Food \& Nutrition Research 2016, 60:30961, no. 308. Available online: http://dx.doi.org/10.3402/fnr.v60.31961 [Accessed 9.12.2016]

Valtion ravitsemusneuvottelukunta (2014). Terveyttä ruoasta - Suomalaiset ravitsemussuositukset 2014. 4. korjattu painos. Juvenes Print - Suomen Yliopistopaino Oy. Tampere 2014. $56 \mathrm{~s}$. Available online: https://www.evira.fi/globalassets/vrn/pdf/ravitsemussuositukset_2014_fi_web.3_es-1.pdf. [Accessed 9.12.2016] 


\section{Sammenfatning}

Kvaliteten af information om fødevarers indholdsstoffer er af stor betydning i betragtning af at data bruges i mange vigtige sammenhænge: nationale kostråd og ernæringssoplysning, mærkning af fødevarer med næringsdeklarationer og epidemiologisk og anden forskning inden fro ernæringsområdet. Prøveindsamling og kemisk analyse af næringsstofindholdet i fødevarer i de nordiske lande data er nødvendig for at opnå data af god kvalitet.

Projektet The Nordic Network on Food Analysis (NFAN), 2013-2016, har fokuseret på at etablere en fælles og enkel nordisk kommunikationsplatform til at dele historik og planer for kemiske fødevareanalyser. Desuden er der fokuseret på at dele viden om udviklingen inden for nye analysemetoder, især vedrørende kostfiber, jod og natrium (salt).

En extranet-side blev oprettet, hvor projektpartnerne kunne opdatere information om deres planer for kemiske fødevareanalyser af næringsindhold. Platformen har vist værdi til udveksling af nyttige informationer, skønt opdateringen af den til tider blev anset for besværlig og ikke motiverende i sig selv. Det kræver mere aktiv koordinering at gennemføre dette.

Sammenlignende analyser af kostfiber-, jod- og natriumindhold i udvalgte nordiske fødevarer fra de forskellige nordiske lande blev gennemført med ekstern finansiering. Resultater blev diskuteret og udbredt i og udenfor projektgruppen. Disse analyser og netværkets sammenligning af berigelsespraksis i landende viste, at der er flere årsager til forskelle i næringsindhold, selvom samme analysemetode og - procedurer anvendes. Forskellene i næringsstofindhold i fødevarerne mellem landene i analyseprojektet skyldtes især forskelle i berigelsesprogram mer og fodringspraksis.

NFAN-netværket har holdt tre fysiske møder og et åbent satellit symposium, som primært har opdateret partnerne om udviklingen i de øvrige lande og givet mulighed for at drøfte fremtidsvisioner - og endda vilde ideer. Møderne er blevet højst værdsat bl.a. fordi der er en oplevelse af at den kritiske masse for kompetencer både inden for kompilering af fødevaredata og fødevarekemiske analyser inden alle de nordiske lande er ved at være nået, og her var et forum for drøftelse af generelle udfordringer og strategier for en bedre udbredelse af fødevaredata og relaterede emner til brugere og interessenter. 
Netværket anbefaler følgende aktiviteter i fremtiden:

- De nordiske lande bør fortsat holde hinanden orienteret om planer for kemiske fødevareanalyser for bl.a. at facilitere mulige fælles analyser. Der er behov for en velstruktureret og brugervenlig kommunikationsplatform hvor alle informationer updateres og gemmes.

- Nye analysedata bør deles mellem de nordiske lande (og andre)og indgå i fremtidig compilering.

- Baggrundsinformation om analyseret næringsindhold, $f_{x}$ prøveudtagningsprocedurer, metoder, prøvebeskrivelser ( $f x$ berigelse- og fodringspraksis) er afgørende for brugerne og skal kunne findes sammen med oplysninger om næringsindholdet.

- Fælles nordisk uddannelse af aktører både inden for fødevareanalyser og compilering af indholdsdata bør overvejes for at sikre fremtidig høj kvalitet af data.

- Harmonisering af metoder og procedurer for de kemiske analyser ud fra eksisterende retningslinjer (Greenfield \& Southgate, 2003) bør fotsætte.

- Procedurer for brugen af eksisterende data re-evalueres, $\mathrm{fx}$ ved at gennemføre et projekt inspireret af Norfoods 2000 projektet (Norfoods 2000-project group, 2002). 


\section{Yhteenveto}

Elintarvikekoostumustiedon laadulla on erittäin suuri merkitys, sillä sitä hyödynnetään hyvin laajalti ja varsin tärkeissä asiayhteyksissä, kuten ravintokuidun kansallisen saantisuosituksen määrittämisessä, elintarvikkeiden pakkausmerkintöjen laatimisessa ja epidemiologisissa tutkimuksissa. Jotta Pohjoismaissa kulutetuista elintarvikkeista olisi saatavilla laadukasta tietoa, kiinnostavien ravintoaineiden määrittäminen vaatii kattavan näytteenoton ja kemiallisia analyysejä.

Pohjoismainen Elintarvikeanalyysiverkosto -projekti, joka toteutettiin vuosina 2013-2016, keskittyi luomaan yhteistä, yksinkertaista viestintäalustaa, jonka välityksellä verkoston jäsenet voisivat jakaa tietoa tekemistään kemiallisista elintarvikeanalyyseistä ja tulevista analyysisuunnitelmistaan. Verkoston tavoitteena oli myös jakaa tietoa uusista analyysimenetelmistä, varsinkin ravintokuidun, jodin ja natriumin (suola) määrittämisen osalta.

Verkoston jäsenille perustettiin viestintäalustaksi extranet-sivusto, jonne he päivittivät tietoja tekemistään kemiallisista analyyseistä oman maansa osalta, jotta muut jäsenmaat olisivat tietoisia niistä. Viestintäalusta koettiin informatiiviseksi, vaikkakin sen ajan tasalla pitäminen koettiin välillä hankalaksi tai unohtui kokonaan. Verkoston toiminnan säilyttämiseksi tarvitaan aktiivista koordinointia, jotta verkosto olisi hyödyllinen.

Tietyistä pohjoismaisista elintarvikkeista tehtiin vertailevia, ulkoisilla varoilla toteutettuja ravintokuitu-, jodi- ja natriummäärityksiä. Tulokset analysoitiin ja niistä tiedotettiin verkoston jäsenille sekä pohjoismaisille asiantuntijoille. Vaikka jäsenmaat olivat noudattaneet samoja analyysimenetelmiä ja -käytäntöjä, vertaileva analyysi osoitti tulosten poikkeavan toisistaan. Verkosto selvitti jäsenmaiden analyysiolosuhteita, joiden perusteella voitiin todeta useita syitä tulosten eroille. Erilaiset ravintoainekoostumukset johtuivat pääosin jäsenmaiden erilaisista elintarvikkeiden täydennyskäytännöistä ja eroista rehujen koostumuksessa.

Pohjoismainen Elintarvikeanalyysiverkosto järjesti kolme tapaamista ja yhden avoimen satelliittisymposiumin projektin aikana. Tapaamisissa jäsenmaat kertoivat alan kansallisista kehitystoimenpiteistä ja keskustelivat tulevaisuuden visioista - jopa villeistä sellaisista. Tapaamiset koettiin erittäin arvokkaiksi, osin johtuen siitä tosiasiasta, että pätevien elintarvikkeiden koostumustiedon käsittelijöiden ja elintarvikekemistien määrä on vähentynyt kaikissa Pohjoismaissa. Tapaamisissa käsiteltiin projektiin liittyviä tehtäviä, mutta ne toimivat myös keskustelufoorumina, jossa voitiin puida alaan kuuluvia laajempia haasteita sekä strategioita, joilla voitaisiin välittää elintarviketietoa paremmin tiedon käyttäjille. Tärkeänä keskustelunaiheena oli myös, kuinka parantaa elintarviketietoon liittyvää dialogia elintarviketeollisuudessa toimivien tiedon tuottajien ja tiedon käyttäjien sekä muiden sidosryhmien välillä. 
Tulevaisuutta ajatellen NFAN-verkosto on suositellut seuraavia toimenpiteitä:

- Pohjoismaiden tulisi jatkossakin pitää muut verkoston jäsenmaat ajan tasalla elintarvikkeiden ravintoaine-analyysisuunnitelmistaan, mikä helpottaisi mahdollisten yhteismääritysten suunnittelua ja toteutusta sekä muuta yhteistoimintaa ja analyysimenetelmien kehittämistä. Tulevaisuudessa on jatkuvaa tarvetta käyttäjäystävälliselle ja helppokäyttöiselle yhteiselle viestintäalustalle, jonne kaiken tarvittavan tiedon voisi tallettaa ja päivittää.

- Uudet kemiallisten analyysien avulla määritetyt koostumustiedot tulisi siirtää elintarvikekoostumustietokantoihin ja niitä tulisi hyödyntää entistä laajemmin.

- Ravintoaineiden määritykseen liittyvät taustatiedot, kuten näytteenotto, menetelmät, näytteen kuvailu (esim. täydennyskäytännöt, eläinrehujen käyttö ja laatu) ovat ratkaisevaa tietoa tietojen jatkokäyttäjille ja siksi tulosten tulkintaan tarvittavat taustatiedot tulisi välittää tulosten yhteydessä.

- Nuorille pohjoismaisille elintarvikeanalyysi-ja -koostumus-tietojen parissa toimiville voisi harkita järjestettäväksi yhteistä yhteistä koulutusta, jotta laadukkaan elintarviketiedon tuotanto ja asianmukainen käyttö varmistetaan myös tulevaisuudessa.

- Elintarvikkeiden koostumustiedon tuottamisen harmonisointia tulisi edelleen jatkaa vakiintuneiden ohjeistuksien mukaan (esim. Greenfield \& Southgate, 2003).

- Olemassa olevan elintarvikkeiden koostumustiedon käyttöä koskevia sääntöjä ja toimenpiteitä tulisi arvioida uudelleen. Tämä voitaisiin toteuttaa arvioimalla ravintoainepitoisuuksien laskentaan liittyvät käytänteet ja vertailemalla nykyään käytössä olevilla menettelytavoilla saatavia tuloksia 2000-luvun alussa toteutetuin Norfoods 2000-projektissa käytetyin menetelmin (Norfoods 2000 projektiryhmä, 2002). 


\section{Útdráttur}

Gæði gagna um efnainnihald matvæla eru mjög mikilvæg í ljósi mikilvægis gagnanna fyrir ráðleggingar um mataræði á landsgrundvelli, næringaryfirlýsingar og faraldsfræðilegar rannsóknir. Til að vönduð gögn um matvæli sem neytt er á Norðurlöndunum séu fáanleg, parf sýnatöku og efnamælingar fyrir pau næringarefni sem máli skipta.

Verkefnið Norræna samstarfsnetið um matvælaefnagreiningar (NFAN), sem stóð yfir á árunum 2013-2016, fól í sér að mynda sameiginlegan og einfaldan samskiptavettvang til að deila upplýsingum og áætlunum um matvælaefnagreiningar. Einnig var lögð áhersla á að deila upplýsingum um próun á sviði nýrra greiningaraðferða, sérstaklega varðandi trefjaefni, joð og natríum (p.e. salt).

Sett var upp samskiptanetsíða par sem pátttakendur uppfærðu matvælaefnagreiningar sínar svo aðrir fengju upplýsingar um pær og gætu skoðað pær. Netsiðan pótti upplýsandi enda pótt uppfærsla hennar krefðist oft fyrirhafnar, en hvatning til uppfærslu var oft lítil. Til að koma að gagni parf svona starfsemi að lúta virkri samræmingu.

Auk pessa voru framkvæmdar greiningar á trefjum, joði og natríum í völdum norrænum matvörum með utanaðkomandi fjármögnun og niðurstöðum var deilt með aðstandendum verkefnisins og fleirum. Samanburðargreiningar og samanburður á íblöndun næringarefna í pátttökulöndunum sýndu nokkrar ástæður ólíkra niðurstaðna pegar sömu greiningaraðferðum og ferlum var beitt. Meginástæða ólíks styrks næringarefna í matvörum eftir löndum eru mismunandi íblöndun næringarefna og aðferðir við fóðrun dýra í löndunum.

NFAN verkefnið hélt prjá fundi og skipulagði opið netmálping sem voru vettvangur til að upplýsa pátttakendur um framgang í hverju landi og til að ræða framtíðarsýnir, jafnvel framúrstefnulegar hugmyndir. Fundunum var vel tekið, að hluta vegna minni mannafla og færni við gagnaöflun og efnagreiningar innan allra Norðurlandanna. Umræðurnar snérust um efni verkefnisins en voru einnig vettvangur fyrir umræður um frekari áskoranir í greininni og til að gera áætlanir um betri leiðir til að dreifa matvælatengdum upplýsingum til notenda og hagsmunaaðila.

Samstarfshópurinn lagði til eftirfarandi um framtíðaraðgerðir:

- Norðurlöndin ættu að upplýsa hvert annað um áformaðar matvælaefnagreiningar til að greiða fyrir mögulegum sameiginlegum greiningum og til að auðvelda önnur samlegðartækifæri. pað er áframhaldandi pörf fyrir vel skipulagða og notendavæna samskiptavettvanga, líka i framtíðinni pegar allar upplýsingar eru geymdar og uppfærðar.

- Nýjar efnagreininganiðurstöður ætti einnig i framtíðinni að skrá í matvælagagnagrunna og nýta meira. 
- Grunnupplýsingar um niðurstöður mælinga á næringarefnum, t.d. sýnatökuaðferðir, efnagreiningaaðferðir, lýsing á sýnum (t.d. íblöndun næringarefna og fóđrun dýra), eru ómissandi fyrir pá sem nota gögnin og pví er mikilvægt að peim sé dreift með mæliniðurstöðum.

- Huga ætti að pví að koma upp norrænu pjálfunarprógrammi fyrir ungt fólk sem starfar við matvælaefnagreiningar og söfnun upplýsinga um efnasamsetningu matvæla til að tryggja gæði niðurstaðna i framtíðinni.

- Samræming við vinnslu upplýsinga um efnainnihald matvæla ætti áfram að byggjast á traustum leiðbeiningum (Greenfield \& Southgate, 2003).

- Endurmeta ætti reglur og aðferðir fyrir notkun gagna um efnainnihald matvæla sem nú eru fáanleg. Petta mætti gera með pví að endurmeta meðhöndlun gagna um næringarefni, p.e. að uppfæra hið eldra Norfoods 2000 verkefni (Norfoods 2000-project group, 2002). 


\section{Sammendrag}

Datakvaliteten på næringsinnhold i matvarer er av stor betydning med tanke på den omfattende og betydningsfulle bruken av disse datene; til nasjonale kostråd, merking av matvarer og i epidemiologisk forskning. Mat som konsumeres i Norden bør tas prøver av og analyseres for å ha næringsstoffdata av god kvalitet.

Det nordiske matvareanalyse nettverksprosjektet (NFAN), som ble gjennomført i 2013-2016, fokuserte på å skape en felles, enkel kommunikasjonsplattform for å dele historikk og planer for analyser av matvarer. I tillegg ble det fokusert på å dele erfaringer om nye analysemetoder, særlig om kostfiber, jod og natrium (salt).

Det ble opprettet en extranet-side der prosjektdeltagerne kunne oppdatere planene for matvareanalyser, slik at alle i prosjektet fikk tilgang til denne informasjonen. Plattformen var informativ, men det var tungvint å oppdatere den. Slike aktiviteter trenger en aktiv koordinering for å være nyttige.

Sammenlignende analyser av fiber, jod og natrium i utvalgte nordiske matvarer ble gjennomført med ekstern finansiering. Resultatene ble delt, diskutert og spredt $\mathrm{i}$ prosjektgruppen og til et bredere publikum. De komparative analysene og sammenligningen av berikningspraksis i de nordiske landene avdekket flere årsaker til at det forekommer sprikende resultater til tross for at samme analysemetode og prosedyrer blir brukt. De viktigste årsakene til at næringsstoffinnholdet varierer mellom landene er ulikheter i berikningspraksis og i dyrefôr.

NFAN-nettverket organiserte tre fysiske møter og et åpent satelittsymposium i løpet av prosjektet. Møtene fungerte som en arena der prosjektdeltagerne kunne oppdatere hverandre om hva som skjer på området og for å diskutere en fremtidig visjon for arbeidet og nye ideer. Møtene ble høyt verdsatt, blant annet fordi kompetansen er avtagende hos kjemikerne og de andre som jobber med matvaredatabaser på nasjonalt nivå i alle de nordiske landene. Diskusjonene omhandlet oppgavene i prosjektet, men også andre utfordringer og planlegging av hvordan informasjon om matvaredata kan spres til brukere på en bedre måte.

For fremtidige aktiviteter anbefaler nettverket at:

- De nordiske landene bør fortsette å informere hverandre om planer for analyse av matvarer for å muliggjøre samarbeid om analyser, metodeutvikling og andre synergieffekter. Det er fremdeles behov for en enkel og strukturert kommunikasjonsplattform der all informasjon lagres og oppdateres kontinuerlig.

- Nye analysedata bør i større grad benyttes. Dataene bør også i fremtiden publiseres i matvaredatabasene.

- Bakgrunnsinformasjon om de analyserte næringsstoffverdiene, for eksempel uttaksprosedyrer, metoder, beskrivelse av utvalg (berikningspraksis, bruk av 
dyrefôr i landet etc.) er viktig for brukerne av dataene. Informasjonen bør derfor følge næringsstoffverdiene.

- Et felles nordisk opplærings program for unge aktører som jobber med analyser av matvarer og annet matvaredataarbeid bør vurderes for å sikre at også fremtidige data er av en høy kvalitet.

- Arbeid med harmonisering av matvaredata etter etablerte retningslinjer (Greenfield \& Southgate, 2003) bør fortsette.

- Evaluering av nåværende regler og prosedyrer i matvaredataarbeidet bør gjennomføres. For eksempel et evalueringsprosjekt tilsvarende det tidligere Norfoods 2000-prosjektet (Norfoods 2000-project group, 2002). 


\section{Sammanfattning}

Datakvalitén för livsmedels näringsinnehåll är av stor vikt med tanke på den omfattande och betydelsefulla användningen av dessa data, för nationella kostråd, näringsdeklarationer samt i epidemiologisk forskning. Livsmedel som konsumeras i Norden behöver provtas och analyseras för att data av bra kvalité om näringsinnehållet ska kunna tillhandahållas.

Det Nordiska nätverket för livsmedelsanalysprojekt (NFAN), verksamt 2013-2016, har haft som fokus att skapa en gemensam, enkel kommunikationsplattform för att dela historik och planer för analys av näringsämnen i livsmedel. Ytterligare ett fokusområde har varit att dela erfarenheter av utvecklingen av nya analytiska metoder, speciellt vad gäller kostfibrer, jod och natrium (t ex salt).

En plattform i egenskap av en hemsida skapades för deltagarna att dela sina planer för livsmedelsanalys med varandra. Plattformen har upplevts som informativ, men att hålla den uppdaterad har upplevts som besvärligt eller glömts bort. Denna typ av aktivitet kräver aktiv koordination för att vara användbar.

Jämförande haltanalyser av fibrer, jod och natrium i ett urval av Nordiska livsmedel genomfördes med externa medel. Resultaten delades, diskuterades och spreds inom projektgruppen samt till en bredare publik. Analysresultaten visade på skillnader, även när analyserna gjorts med samma metod och förfarande. Nätverkets undersökning av förhållandena i de olika länderna visade på flera orsaker till detta. De största orsakerna till skillnader mellan länder i näringsinnehåll visade sig vara skillnader $i$ tillämpningar av berikning samt i tillvägagångssätt vid djurutfodring.

I projektet har NFAN anordnat 3 fysiska träffar och 1 öppet satellitsymposium, vilka har fungerat plattformar för att uppdatera deltagarna om varandras nationella utvecklingsarbete inom området samt för att diskutera framtida visioner - även vilda idéer. Mötena har varit mycket uppskattade, inte minst för att den kritiska massan för kompetens på nationell nivå är på nedgång, både vad gäller kompilerare och livsmedelskemister. Diskussionerna fokuserade på projektets uppgifter, men fungerade även som fora att diskutera utmaningarna inom området $\mathrm{i}$ ett bredare perspektiv samt strategier hur frågor som rör livsmedelsdata bättre kan spridas till dataanvändare och andra intressenter.

Framtida aktiviteter nätverket rekommenderar är, att:

- De Nordiska länderna även i fortsättningen håller varandra informerade om sina planer för analysprojekt av näringsämnen i livsmedel, för att möjliggöra att projekten kan drivas gemensamt, andra synergieffekter samt metodutveckling. Behovet kvarstår av en välstrukturerad och lättillgänglig kommunikationsplattform där all information samlas och uppdateras kontinuerligt. 
- Nya analysdata även i framtiden delas mellan livsmedelsdatabaser för bredare användning.

- Bakgrundsinformation som är av avgörande betydelse för användare om analysresultat för näringsämnen delas i anslutning till värdena, t ex provtagning, metoder, beskrivning av livsmedelsprov (t ex hur berikning och djurutfodring görs i det land där provtagning utförts).

- Övervägande görs att upprätta ett gemensamt Nordiskt träningsprogram för nya aktörer inom analys av näringsämnen i livsmedel och kompilering av livsmedelskompositionsdata för att säkerställa upprätthållande av kvalitén i data även i framtiden.

- Arbetssätten för framtagande av näringsinnehåll i livsmedel även fortsättningsvis harmoniseras i enlighet med etablerade vägledningar (Greenfield \& Southgate, 2003).

- Nuvarande regler och arbetssätt för livsmedelsdataarbete utvärderas. Detta kan genomföras genom ett utvärderingsprojekt likt det tidigare Norfoods 2000 (Norfoods 2000-project group, 2002). 


\section{Appendices}

- Appendix 1a-c. Agendas of the network face-to-face meetings .

- Appendix 2. Sampling protocol for comparative food analyses.

- Appendix 3. Examples of fortification programmes of vitamins and minerals, which may result inconsistent food composition of equivalent foods in the Nordic Countries.

- Appendix 4. Contact persons, addresses and contact information.

Appendix 1. Agendas of the network face-to-face meetings 20142016

Appendix 1 a. Nordic Food Analysis Network -meeting, Helsinki April 1-2, 2014

Venue: Tieteiden talo (Kirkkokatu 6, 00170 Helsinki)

Tuesday 1.4.2014

- 11:00 Opening of the meeting

- 11:15 Country presentations

- Introducing the working group members

- Latest analyses and upcoming projects

- 13:00 Lunch (at own cost)

- 14:00 Fiber: the new method (AOAC 2011.25)

- Helena Pastell from Evira presents the new method

- Methods currently in use in each country

- Discussion:

a) Pros and cons old vs. new

b) Willingness to use the new method

c) Which foods should be prioritized for analysis?

- 15.30 lodine

- Introduction (Taija Kosonen from Evira)

- Current status in each country

- Discussion:

a) Population status and quality in the database

- 17:00 End of day 1 
- 18:30 Dinner in Restaurant Meche (at own cost)

Wednesday 2.4.2014

- 9:00 The New Nordic Diet

- NND-Workshop (Heikki Pakkala)

- What is NND for Nordic countries

- Foods to analyse

a) Foods with many missing values

b) Foods that are useful for several countries

c) Foods that are specific to Nordic countries

d) Foods with significant economic potential

- Debriefing of the workshop session

- Any analysis in this field since Iceland, May 2012

- (National) recommendations concerning NND

- Existing literature

- 12:00 Lunch (at own cost)

- 13: 00 Fatty acid factors

- Astrid Nordbotten

- Discussion:

a) Literature and different factors in use

- 13: 45 Improving the synergy for analysis

- Discussion:

a) Ideas how to improve the synergy

- 14:30 Nordic network in the future

- How to build a functioning network

- Plans for future

- Next meeting

- 15:00 End of day 2 
Appendix 1 b. Nordic Food Analysis Network -meeting, Tallinn June 10-11, 2015

Venue: National Institute for Health Development (Hiiu 42, Tallinn, Estonia).

Wednesday 10.6.2015

- 9.45-11:00 Welcoming coffee

- 10:00 Satellite lecture

- Introduction to the Estonian Nutriediet pro software, Liis Kambek, National Institute for Health Development

- 11:00 Opening of the Nordic Food Analysis Network meeting

- Welcome

- Aims of the meeting

- Introducing the working group members

- Housekeeping issues

- 11:15 Round table

- Country updates - (title+3 slides per country)

- Ann Jõeleht: Estonian FCDB and the new industry-targeted data entry platform

- 12:30 Lunch

- 13:15 Food analyses updates 1

- Fibre: Helena Pastell, Finnish Food Safety Authority Evira, Finland

- Folate: Susanna Kariluoto, Univ. of Helsinki, Finland

- Vitamin K: Rasmus Grönholm, National Food Agency, Sweden

- 14.45 Coffee/refreshments break

- 15.00 OPERA group process

- How to increase harmonization of food composition values in the Nordic countries? (All)

- 16:45 Summary of Day 1

- 17:00 End of Day 1

- 18:30 Walking tour in Old Town Tallinn

- 20:00 Dinner, TBC (at own cost) 
Thursday 11.6.2015

- 9:00 World Café session

- Key issues in improving the Nordic collaboration in the field of food composition (All)

a) orientation to the topic (Liisa Valsta)

b) coffee/refreshments available

- 10:45 Search for future funding

- Discussion (all)

- 11:15 Break

- 11:30 Food analyses updates 2 and short voluntary communications by the network

- lodine - Swedish experiences: Veronica Öhrvik, National Food Agency, Sweden

- lodine - an update: Taija Kosonen, Finnish Food Safety Authority Evira, Finland

- Weight measures and portion sizes for foods: Ellen Kielland (NFSA), Norway

- 13:00 Lunch

- 13:45 Nordic network in the future

- How to further activate the network?

- Plans for future - final meeting in June 2016

- Activities of the network in connection to the Nordic Nutrition Conference, Gothenburg 20-22 June 2016

- 14:45 Evaluation of this meeting and date for the next meeting

- 15:00 End of day 2 
Appendix 1c. Final meeting of the Nordic Food Analysis Network and Satellite symposium arranged by the NFAN, Gothenburg June 19, 2016

Venue: Svenska Mässan, conference rooms R11 and R12.

Sunday 19.6.2016

- 13:00-13:05 Opening of the final internal meeting of the Nordic Food Analysis Network (Liisa Valsta)

- 13:05-14:00 Main results of the NFAN collaboration (the NFAN group)

- 14:00-17:00 Open Satellite Symposium organized by the NFAN project

- Opening of the Symposium (Adjunct prof. Liisa Valsta)

- Evolution and future visions of management and utilization of food composition data in the Nordic countries (Prof. Wulf Becker)

- Recent developments in the European databases on the EuroFIR activities (Dr. Susanne Westenbrink)

- Activities and challenges in harmonizing Nordic Food Composition Databases

a) Activities of the Nordic Food Analysis Network (Adjunct prof. Liisa Valsta)

- Dietary fibre, iodine and salt content in Nordic foods (Dr. Helena Pastell)

- Refreshments

- Dialogue between food composition data and food labelling

a) The role of food composition databases in future nutrient labelling

(Tue Christensen)

- $\quad$ and vice versa - Introduction to Mintel GNPD (Anders Mogensen)

- Final discussion "A Harmonized Nordic Food Composition Database - Why not?"

- 17:00-17:40 Final report of the NFAN - comments to the draft (the NFAN group)

- 17:40-18:10 Discussion: Lessons learned during the project and suggestions for future collaboration (All)

- 18:10-18:20 Final steps and tasks before the end of the project (All)

- 18:20 Closing of the final internal meeting (Adjunct prof. Liisa Valsta) 


\section{Appendix 2. The sampling plan for the Nordic Food Analysis Network - iodine and sodium comparisons 2015}

\section{Sampling plan}

Co-operation among the partners of the Nordic Food Analysis Network (Finland, Denmark, Sweden, Norway, Iceland and Estonia) was planned at the meeting in Tallinn (June 10-11, 2015) concerning iodine and, if possible, sodium analyses.

Matrices: fish, milk, eggs, white sliced wheat toast bread and Edam cheese were chosen as matrices (detailed descriptions of the samples can be found in Table 15). The results will be used by the Nordic Food Analysis Network and are planned to be presented at the Nordic Nutrition Conference in June 2016.

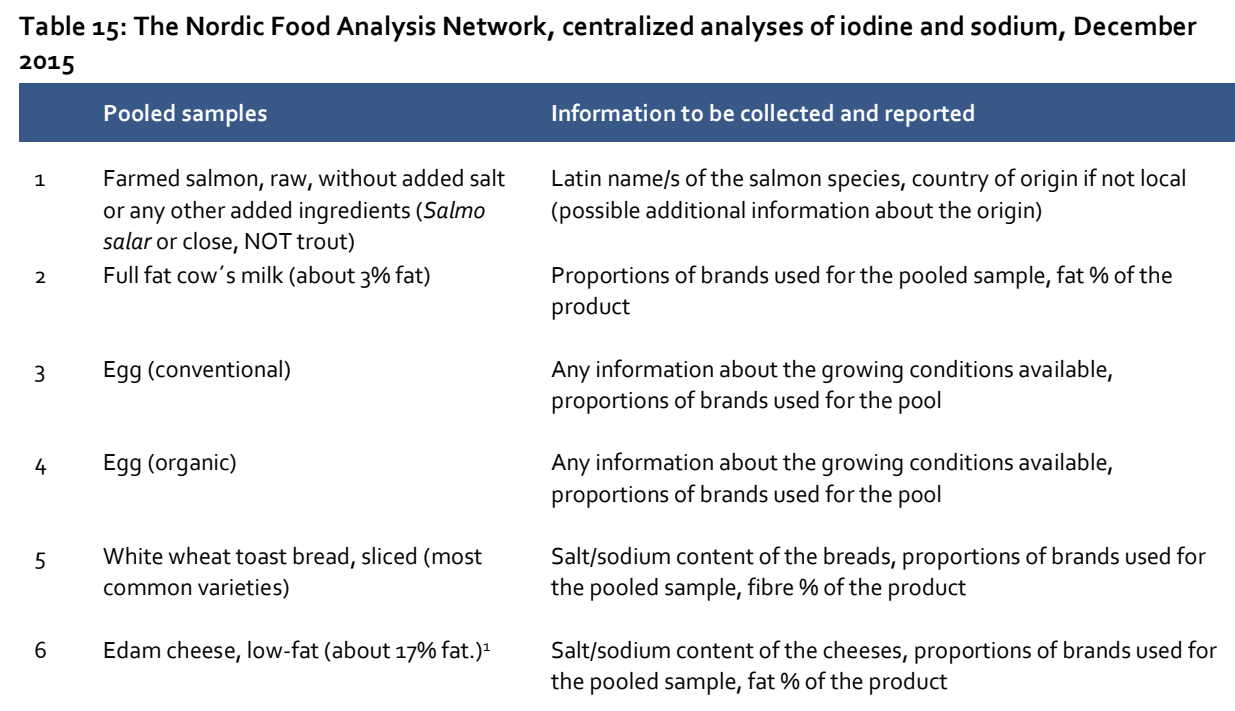

Note: ${ }^{1}$ If low-fat Edam cheese not on market, please provide another type of hard low-fat cheese closest to Edam cheese and describe the sample as clearly as possible (fat \%, salt/sodium \%, brand, cheese type etc.).

Analyses: Measurement of total iodine and sodium according to Table 16. Both iodine and sodium will be measured using the ICP-MS method. 
Table 16: The samples to

\begin{tabular}{|c|c|c|c|c|c|}
\hline \multirow[t]{2}{*}{ Pooled samples } & \multicolumn{5}{|c|}{ Participating country } \\
\hline & Finland (6) & Sweden (6) & Norway (6) & Iceland (5) & Estonia (4) \\
\hline 1) Farmed salmon (Salmo salar or similar) & $I^{1}$ & 1 & 1 & 1 & - \\
\hline 2) Full fat milk (about 3\% fat) & 1 & 1 & 1 & 1 & 1 \\
\hline 3) Egg (conventional) & $\mathrm{I}+\mathrm{Na}^{1}$ & $\mathrm{I}+\mathrm{Na}$ & $\mathrm{I}+\mathrm{Na}$ & $\mathrm{I}+\mathrm{Na}$ & $\mathrm{I}+\mathrm{Na}$ \\
\hline 4) Egg (organic) & 1 & I & 1 & - & - \\
\hline $\begin{array}{l}\text { 5) White wheat toast bread, sliced } \\
\text { (common variety) }\end{array}$ & $\mathrm{I}+\mathrm{Na}$ & $\mathrm{I}+\mathrm{Na}$ & $\mathrm{I}+\mathrm{Na}$ & $\mathrm{I}+\mathrm{Na}$ & $\mathrm{I}+\mathrm{Na}$ \\
\hline 6) Edam cheese, low-fat (about 17\% fat) & $\mathrm{I}+\mathrm{Na}$ & $\mathrm{I}+\mathrm{Na}$ & $\mathrm{I}+\mathrm{Na}$ & $\mathrm{I}+\mathrm{Na}$ & $\mathrm{I}+\mathrm{Na}$ \\
\hline
\end{tabular}

be collected and analyses to be carried out from the samples

Note: $\quad{ }^{1} \mathrm{I}=$ iodine, $\mathrm{Na}=$ sodium

The analyses will be carried out at the Finnish Food Safety Authority Evira (contact information at the end of this document). The Nordic Food Analysis Network, which includes the Nordic countries and Estonia, will collaborate with Evira for the collection of food samples by country-representatives of the Network, according to Table 2. The foods used for this work will be composite samples representative of what is mostly consumed, of the respective sample foods, in each Nordic country. The network countries are kindly asked to collect and send the composite samples from their countries.

\section{Sampling procedure in Finland to be applied as closely as possible by other countries}

Finland has 4 retail groups with known market shares (Table 3). Each retail group contains several store chains. The Finnish samples are selected from each retail group and store chain, with more visits to the stores that have a higher market share. Sampling is done from 12 stores, and 12 samples are collected ( 1 sample/store) and they will be combined into a pooled composite sample. Sampling will be carried out in the Helsinki area. In the case of milk, cheese and white bread, Finnish dairies, mills and factories prepare and evenly distribute their products across the country, thus, decreasing the considerable variations in the quality of the products, in spite of where the products are purchased. This facilitates the sampling, as we do not need to pick samples from other Finnish cities, as the majority of the mostly consumed products are prepared at the major dairies and factories, and their products sold, throughout Finland. 
Table 17: The market shares (\%) and stores of the 4 Finnish trade groups in 2014

$\begin{array}{lll}\text { Trade Group } & \text { Market Share }(\%) & \text { Stores } \\ \text { S-group } & & \\ \text { K-store } & 45,7 & 6 \text { stores ( }{ }^{*} \text { S-market, } 2^{*} \text { Prisma, } 1^{*} \text { Alepa) } \\ \text { Suomen lähikauppa } & 33,1 & 4 \text { stores }\left(2^{*} \text { Citymarket, } 1^{*} \text { K-Supermarket, } 1^{*} \text { K-Market) }\right. \\ \text { Others } & 6,8 & 1 \text { store }\left(1^{*} \text { Valintatalo or Siwa) }\right. \\ & 14,4 \text { (out of which Lidl } 9.2 \%) & 1 \text { store }\left(1^{*} \text { Lidl) }\right.\end{array}$

Note: $\quad *_{1}, 2,3$ : number of stores from each trade group that were chosen for the sampling

In the case of eggs and salmon, greater variation can be expected between the items or specimens. To get representative results, it is important to obtain the samples from different farms or locations, whenever possible.

For more information about the sampling plan: country members that participate in the Total Diet Study (TDS) can do the sampling, according to the TDS sampling plan instructions.

\section{Sample selection}

\section{1) Farmed salmon}

Farmed salmon samples (Salmo salar or the most common species on market) should be checked for being farmed and not wild. Record the scientific name, if available. Collect 12 samples, according to market share, from 12 stores (1 sample/store) by a simple random sampling technique. In the case of more than 1 farmed salmon source in the market, select the sample (about a $400 \mathrm{~g}$ piece (fillet) of farmed salmon/market) from the source/basket that is currently most representative by counter- metres or area. Farmed salmon may be pre-packed, and in this case, pick one package using a simple random sampling technique. In Finland, all farmed salmon is imported from Norway. In Finland, the best places for purchasing salmon samples are fish-stocks.

\section{2) Full-fat milk (fat content around 3\%)}

Collection of full-fat cow's milk samples are based on supply. Milk samples are bought from 12 markets, according to the latest market share. Select the most representative product in shelf-metres ( 1 product $/$ market) in packages of 1 litre $/ \mathrm{kg}$. Assuming that the most representative product is the same in all markets, select other available products as well, as they too are consumed, and therefore, should be part of the sample.

When collecting the same food brands from different markets, try to choose samples from different batches and/or best-before dates. Samples should not expire before pooling and freezing. Samples should be the most representative of their category and traditionally eaten in each country (avoid samples where the content or origin is not clear). 


\section{3) Eggs (conventional)}

The conventional egg samples should be checked for NOT being organically produced and the samples should be based on the supply. Conventional egg samples are bought from 12 markets, according to the latest market share. Select the most representative product, in shelf-metres, in packages of $4-6$ eggs per box/market.

\section{4) Eggs (organic)}

The organic egg samples should be carefully checked to be sure they are organically produced and the samples are based on the supply. Organically produced egg samples are bought from 12 markets, according to the latest market share. Select the most representative product, in shelf-metres, in packages of 4-6 eggs per box/market.

\section{5) White wheat toast bread, sliced (most common varieties)}

Collection of white toast bread samples are based on the supply. Bread samples are bought from 12 markets, according to the latest market share. Select the most representative product, in shelf-metres, (1 product/market) in packages of 15-25 slices. Assuming that the most representative product is the same in all markets, select other available products as well, as they too are consumed, and therefore, should be part of the sample. When collecting the same food brands from different markets, try to choose samples from different batches and/or best-before dates. Samples should not expire before pooling and freezing. If you collect samples from the same batch, select the minimum sample content in order to facilitate pre-treatment. Samples should be the most representative of their category and traditionally eaten in each country (avoid samples where the content or origin is not clear).

\section{6) Edam cheese, low-fat (about 17\% fat)}

Collection of Edam cheese samples is based on the supply. When low-fat Edam cheese is completely unavailable on the market in your country, collect a sample of the closest variety of Edam cheese and with low fat (about 17\%) and carefully record the product information. Edam cheese samples are bought from 12 markets, according to the latest market share. Select the most representative product, in shelf-metres (1 product/ market), in packages of about 300-500 $\mathrm{g}$ or as a cut of a large cheese loaf from the cheese counter. Check that the samples are from different cuts of the original large cheese, i.e. try to avoid picking only specific types of pieces of cheese (e.g. only "corner" pieces), as the salt content, at least, may vary between the inner and outer parts of the original cheese loaf. Assuming that the most representative product is the same in all markets, select other available products as well, as they too are consumed, and therefore, should be part of the sample.

When collecting the same food brands from different markets, try to choose samples from different batches and/or best-before dates. Samples should not expire before pooling and freezing. If you collect samples from the same batch, select the 
minimum sample content in order to facilitate pre-treatment. Samples should be the most representative of their category and traditionally eaten in each country (avoid samples where the content or origin is not clear).

\section{Sample compilation for the analyses}

\section{General instructions}

Label all of the samples with the sample number listed above (using extra caution with the samples from 3 and 4 above, to avoid mixing them up with each other), with a purchasing date(s), pooling date, country name and the name of the person responsible for the sample. Whole, frozen, composite samples can be sent to Evira, where the samples will be ground and homogenized.

Record the weight of each container (made of plastic suitable for food), sampling them separately before freezing, and provide the weights of all of the samples to Evira, with the shipment. Freeze the pooled samples and ship to Evira (address below).

We (Evira) will be happy to answer any of your questions. We kindly ask you to send the samples as soon as possible, before 21 December, 2015. Please note that between 23 December 2015 and 4 Jan 2016 none of the staff responsible for receiving chemical food analyses samples will be at Evira, and therefore, we need to be given notice of any arrivals, well in advance.

\section{Sample specific instructions}

1) Farmed salmon

Farmed salmon samples are cleaned so that they only contain fish meat (skin and bones are removed, if present). Each sample is cut into 8 pieces and $1 / 8$ of the sample is selected, according to random selection (the final composite sample should be an approximately $600 \mathrm{~g}$ pool of farmed salmon).

2) Full-fat milk (fat content around $3 \%$ )

Shake the milk sample in its container before pooling the sample. Take a $0.5 \mathrm{dl}$ sample of each container and pool the aliquots, together, in an unbreakable 1 litre plastic bottle, suitable for food. Weigh the sample before freezing. Freeze the sample before shipping it to Evira.

\section{3) Egg (conventional)}

Take one egg from each container of conventional eggs, break the egg, separate the egg shells from the egg whites and yolks and pool all separated egg whites and yolks together into an approximately 1 litre plastic bottle or container. Weigh the sample before freezing. Freeze the sample before shipping it to Evira. Be careful, not to mix conventional and organic egg samples with each other. 
4) Egg (organic)

Take one egg from each container of organic eggs, break the egg and pool all separated eggs together into an approximately 1 litre plastic bottle or container. Freeze the sample before shipping it to Evira. Be careful, not to mix organic and conventional samples with each other. Weigh the sample before freezing.

5) White wheat toast bread, sliced (most common varieties)

Randomly pick 2 slices of the toast bread from each bread package and pool them, together, in a plastic bag suitable for food. Weigh the sample before freezing. Freeze the sample before shipping it to Evira.

6) Edam cheese, low-fat (about 17\% fat)

Cut each of the cheese samples into 9 pieces and randomly pick 1 sub-piece from each sample and combine them in a container. Weigh the sample before freezing. Freeze the sample before shipping it to Evira.

\section{Contacts}

- Senior Researcher (PhD): Helena Pastell: Mobile phone: +358 50375 og68, email address: helena.pastell@evira.fi

- Senior Researcher (PhD): Tiina Ritvanen: Mobile phone: +358 040489 3415, email address: tiina.ritvanen@evira.fi

- Finnish Food Safety Authority Evira. Research and Laboratory Department, Chemistry and Toxicology Research Unit/Helena Pastell, Mustialankatu 3, FI-oo79o Helsinki, Finland 


\section{Appendix 3. Examples of fortification programmes of vitamins and minerals, which may result inconsistent food composition of equivalent foods in the Nordic Countries}

Table 18: Selected fortification programmes of vitamins in the Nordic Countries. Fortification of nutrients per food groups (unit/10og food)

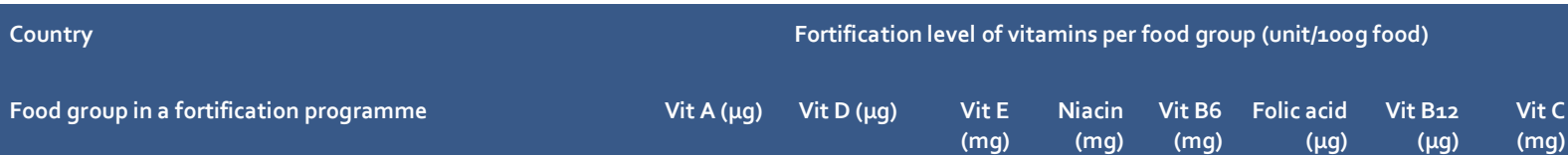

Finland

Margarines and other fat spreads ${ }^{1)}$

Milk and liquid milk products ${ }^{2-3}$

Liquid soy products ${ }^{1}$

(ma)

\section{Norway}

Margarine, oils and other fat spreads 4)

Butter 5)

$800 \quad 20$

Milk

$\begin{array}{rr}800 & 20 \\ 1 \\ 1 \\ \leq 900 \quad \\ \\ 0.9-1.5 \text { RE } & \leq 10 \\ & \leq 10 \\ & 1.0\end{array}$

Fatblends and margarine ${ }^{6)}$

Milk $<1.6 \%$ fat ${ }^{6}$ )

$\begin{array}{cc}400 & 5 \\ & 1 \\ 5 & 1\end{array}$

Butter spread, $40 \%$ fat

Liquid milk, only 3 products 7 )

Milk for children $0.5^{-2}$ year, fortified

\section{Denmark}

Margarine and spreads (spreadable and liquid) ${ }^{8)}$

Milk ${ }^{8)}$

Milk based drinks (fermented and/or with aroma) ${ }^{8)}$

Fermented milk products (beverages not included) ${ }^{8)}$

Lactose free milk ${ }^{8)}$

Condenced milk ${ }^{8)}$

Fermented lactose free milk products (beverages not included) ${ }^{8)}$

900

Soy, rice and oatbased alternatives to fermented milk

products (beverages not included) ${ }^{8)}$

Rice drinks and soy drinks ${ }^{8)}$

Rye bread ${ }^{8)}$

Wheat flour ${ }^{8)}$

$\begin{array}{rr}900 \quad 20 & 20 \\ 1.5 & \\ 1.5 & \\ 4 & \\ 2.0 \\ 2.6 \\ 1.0 \\ 0.75 \\ \\ 0.75 \\ 1.5\end{array}$

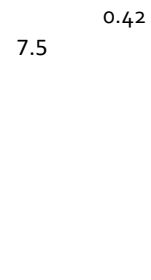

$5 \cdot 3$

150

Note: ${ }^{1)}$ Voluntary according to Regulation (EC) No 1925/2006.

2) The National Nutrition Council recommends fortifying milk products with vitamin D April 2010 (in Finnish).

3) Ministry of Agriculture and Forestry on fortifying fat free organic milk with vitamin D 1 September 2016 (web release in Finnish).

4) The listed food groups are the Norwegian food groups fortified based on public health reasons.

5) Norway follows the EU regulations on fortification, and food producents may apply for fortifying other foods as well.

6) Mandatory regulated by SLVSF 1983:2.

7) Relatively small portion of milk consumption.

${ }^{8)}$ Act no 577 of 02/06/2016. Act on addition of nutrients to food. (General acceptances for addition of vitamins and minerals to certain products (voluntary addition) (in Danish: Bekendtgørelse om tilsætning af næringsstoffer til fødevarer BEK nr 577 af 02/06/2016 Gennerelle tilladelser). 
Table 19: Selected fortification programmes of minerals and trace elements in the Nordic Countries. Fortification of nutrients per food groups (unit/10og food)

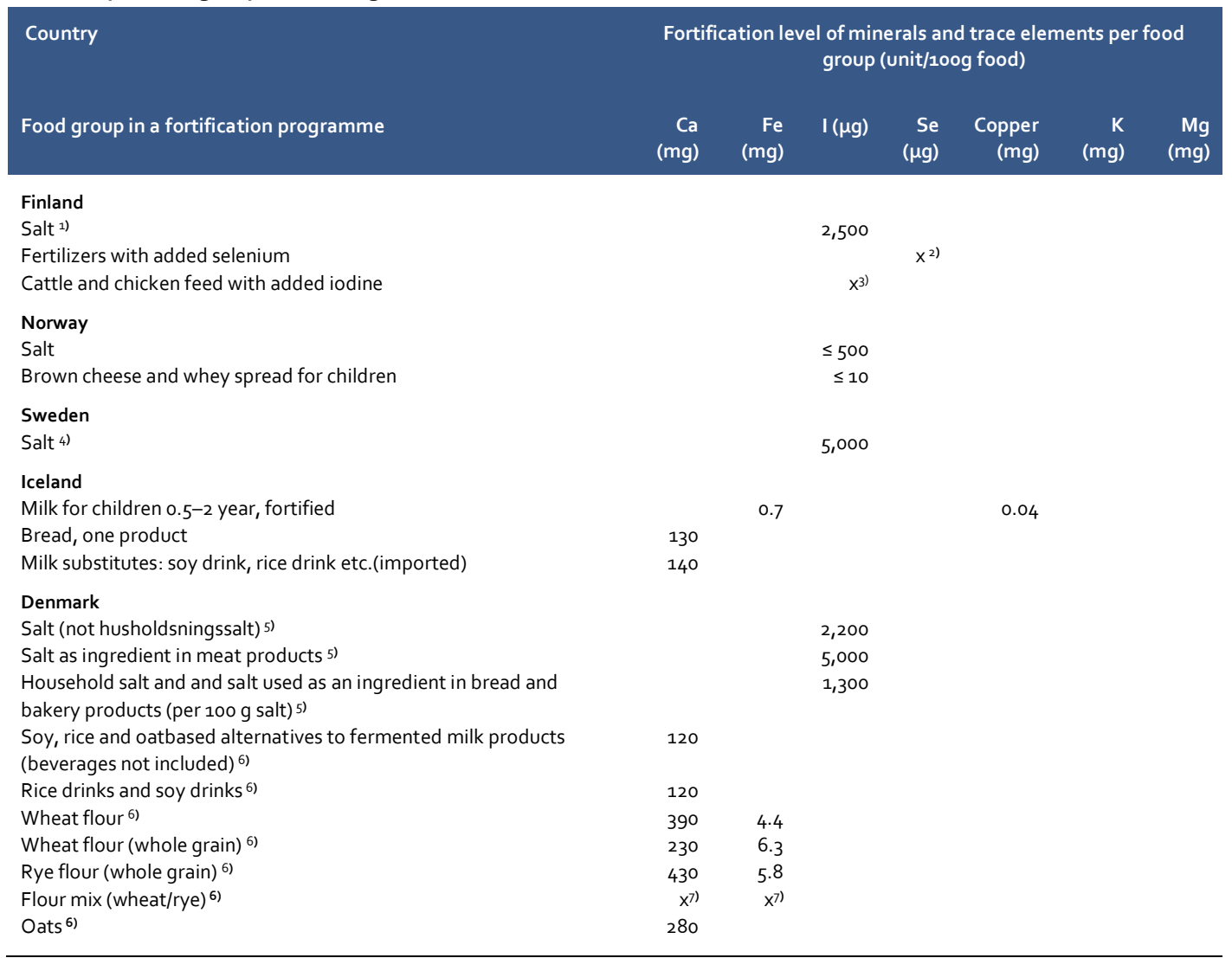

Note: 1) The National Nutrition Council recommends comprehensive use of iodized salt 10 February 2015 (in Finnish). 2) The Agrifood Research (MTT) and its Selenium working group recommends supplementation of fertilizers with sodium selenate $(15 \mathrm{mg} / \mathrm{kg})$.

3) European Commission. (2005). Regulation (EC) No. 1459/2005 amending the conditions for authorisation of a number of feed additives belonging to the group of trace elements.

4) Voluntary fortification in Sweden.

5) Danish Order concerning mandatory addition of iodine to salt (mandatory fortification with iodine of household salt, and salt used as an ingredient in bread and bakery products with iodine at a level of $13 \mathrm{mg}$ iodine per kg salt) Bekendtgørelse om tilsætning af jod til husholdningssalt og salt i brød og almindeligt bagværk m.v. BEK nr 1318 af 11/12/2014.

6) Act no 577 of 02/06/2016. Act on fortification of foods. (General acceptances for addition of vitamins and minerals to certain products (voluntary addition)) (in Danish: Bekendtgørelse om tilsætning af næringsstoffer til fødevarer BEK nr 577 af 02/06/2016 Gennerelle tilladelser).

7) "As stated for wheat flour or corresponding to mixture ratio/proportion". 


\section{Appendix 4. Contact persons, addresses and contact information}

\section{Finland}

Project leader

- Prof. Suvi Virtanen, National Institute for Health and Welfare (THL), Department of Public Health Solutions, Nutrition Unit, Postal address: P.O. Box 30, Fl-00271 Helsinki, Mannerheimintie 166, Helsinki, Tel: +358 295246000 (Exchange), suvi.virtanen@thl.fi

Project info-coordinators

- Jenna Rautanen, M.Sc. (2013-2014) and, Dr. Liisa Valsta (2015-2016), National Institute for Health and Welfare (THL), Department of Public Health Solutions, Nutrition Unit, Postal address: P.O. Box 30, Fl-00271 Helsinki, Mannerheimintie 166, Helsinki, Tel: +35829524600o (Exchange), jenna.rautanen@thl.fi, liisa.valsta@thl.fi

Other editors

- Sanni Aalto, M.Sc., National Institute for Health and Welfare (THL), Department of Public Health Solutions, Nutrition Unit, Postal address: P.O. Box 30, FI-00271 Helsinki, Mannerheimintie 166, Helsinki, Tel: +358 295246000 (Exchange), sanni.aalto@thl.fi

- Dr. Helena Pastell, Finnish Food Safety Authority Evira, Research and Laboratory Department, Chemistry and Toxicology Research Unit, Mustialankatu 3, 00790 Helsinki, Tel: +358295300400 (Exchange), helena.pastell@evira.fi

\section{Contact persons of other participating countries}

Denmark

- Tue Christensen, M.Sc., Division of Risk Assessment and Nutrition, Technical University of Denmark, National Food Institute, Mørkhøj Bygade 19, Building C, 2860 Søborg, Tel: +45 45252525 (Exchange), tuchr@food.dtu.dk

- Ellen Trolle, M.Sc., Division of Risk Assessment and Nutrition, Technical University of Denmark, National Food Institute, Mørkhøj Bygade 19, Building C, 2860 Søborg, Tel: +4545252525 (Exchange), eltr@food.dtu.dk

\section{Estonia}

- Ann Jõeleht, M.A., National Institute for Health Development, Department of Surveillance and Evaluation, Hiiu 42, 11619 Tallinn, Tel: +372 6593900 (Exchange), ann.joeleht@tai.ee 
Iceland

- Ólafur Reykdal, M.Sc., Matis - Icelandic Food and Biotech R\&D, Vinlandsleid 12, IS-113 Reykjavik, Tel: +354 4225000 (Exchange), olafur.reykdal@matis.is

Norway

- Ellen Kielland, M.Sc. , Norwegian Food Safety Authority, Labelling and Quality Section, Postal address: P.O.Box 383, N-2381 Brumunddal, Tel: +4722400000 (Exchange), ellen.kielland@mattilsynet.no

- Jorån Østerholt Dalane, M.Sc., The Norwegian Food Safety Authority, Labelling and Quality Section, Postal address: P.O.Box 383, , N-2381 Brumunddal, Tel: +47 22400000 (Exchange), joran.osterholt.dalane@mattilsynet.no

\section{Sweden}

- Dr. Veronica Öhrvik, Swedish National Food Agency, Science Department, Postal address: Box 622, SE-751 26 Uppsala, Tel: +461817 5500 (Exchange), veronica.ohrvik@slv.se

- Hanna Sara Strandler, FL, Swedish National Food Agency, Science Department, Postal address: Box 622, SE-751 26 Uppsala, Tel: +46 18175500 (Exchange), hannasara.strandler@slv.se 
Nordic Council of Ministers

Nordens Hus

Ved Stranden 18

DK-1061 Copenhagen K

www.norden.org

\section{Nordic co-operation on food information}

The Nordic Food Analysis Network project (NFAN, 2013-2016) focused on creating a common, simple communicational platform to share history and plans on chemical food analyses. This report describes the activities that have taken place in the area of chemical food analysis, for the national food composition databases of the Nordic countries, at the national level, since 2000 and specific activities of this network between the years of 20132016. This network picked fibre, iodine and sodium as specific nutrients to focus on during this project, and comparative analyses of selected Nordic food items were carried out during this project with external funding. The results of the activities are summarized in this project report. 